University of Nebraska - Lincoln

DigitalCommons@University of Nebraska - Lincoln

\title{
Late Cenozoic oscillations of Antarctic ice sheets revealed by provenance of basement clasts and grain detrital modes in ANDRILL core AND-1B
}

\author{
Franco M. Talarico \\ Università di Siena, talarico@unisi.it \\ Robert M. McKay \\ Antarctic Research Centre, Victoria University, Wellington, New Zealand, robert.mckay@vuw.ac.nz \\ Ross D. Powell \\ Northern Illinois University, ross@geol.niu.edu \\ Sonia Sandroni \\ Università di Siena, sandroni@unisi.it \\ Tim Naish \\ Victoria University of Wellington, NEW ZEALAND, tim.naish@vuw.ac.nz
}

Follow this and additional works at: https://digitalcommons.unl.edu/andrillrespub

Part of the Environmental Indicators and Impact Assessment Commons

Talarico, Franco M.; McKay, Robert M.; Powell, Ross D.; Sandroni, Sonia; and Naish, Tim, "Late Cenozoic oscillations of Antarctic ice sheets revealed by provenance of basement clasts and grain detrital modes in ANDRILL core AND-1B" (2011). ANDRILL Research and Publications. 48.

https://digitalcommons.unl.edu/andrillrespub/48

This Article is brought to you for free and open access by the Antarctic Drilling Program at DigitalCommons@University of Nebraska - Lincoln. It has been accepted for inclusion in ANDRILL Research and Publications by an authorized administrator of DigitalCommons@University of Nebraska - Lincoln. 


\title{
Late Cenozoic oscillations of Antarctic ice sheets revealed by provenance of basement clasts and grain detrital modes in ANDRILL core AND-1B
}

\author{
F. M. Talarico, ${ }^{1}$ R. M. McKay, ${ }^{2}$ R. D. Powell, ${ }^{3}$ S. Sandroni, ${ }^{4}$ and T. Naish ${ }^{2}$ \\ 1. Dipartimento di Scienze della Terra, Università di Siena, Via Laterina 8, Siena, Italy \\ 2. Antarctic Research Centre, Victoria University, Wellington, New Zealand \\ 3. Department of Geology and Environmental Geosciences, Northern Illinois University, DeKalb, IL, USA \\ 4. Museo Nazionale dell' Antartide, Università di Siena, Via Laterina 8, Siena, Italy \\ Corresponding author - F. M. Talarico, tel 39 0577233812, fax 39 0577233938, email talarico@unisi.it
}

\begin{abstract}
Petrological investigations of the sand fraction and of granule- to cobble-sized clasts in the Plio-Pleistocene sedimentary cycles of the AND-1B drill core at the NW edge of the Ross Ice Shelf (McMurdo Sound) highlight significant down-core modal and compositional variations. These variations provide: (i) direct information about potential source regions during both glacial maxima and minima; and (ii) evidence of an evolving provenance, documented by long-term shifts in compositional patterns that can be interpreted as reflecting variations in ice volume and ice sheet thermal regimes and changes in paleogeography related to the emergence of several volcanic centers during the deposition of the drill core over the past ca. 3.5 Ma.

The most significant change in diamictite provenance (identified at 82.7 meters below the sea floor, mbsf), coincides with a change in sedimentary cycle architecture from sequences that are dominated by diamictites (Mid-Late Pleistocene, above $82.7 \mathrm{mbsf}$ ) to sequences characterized by cycles of diamictite (subglacial) and diatomite (open-marine) deposition (Pliocene, below $82.7 \mathrm{mbsf}$ ). In the Mid-Late Pleistocene glacial/interglacial cycles diamictites show high amounts of Skelton-Mulock sourced clasts, supplied from both basement and overlying Beacon and Ferrar supergroups, and they also include a variable contribution from reworking of glacial sediments that were deposited during earlier glacial activity.

In the Pliocene to early Pleistocene diatomite-diamictite cycles basement clast compositions indicate the same provenance (Mulock-Skelton) but the main debris load was picked up from volcanic centers in the McMurdo Sound area. Similarly, associated glacial minima sediments (i.e., diatomite intervals) are dominated by volcanic clasts suggesting calving of glaciers from Ross Island or the Koettlitz Glacier region during interglacials.

In agreement with previous glaciological reconstructions and numerical ice sheet models, the provenance of glacially transported material is firmly identified in the region between Ross Island and the Skelton-Mulock glacier area (South Victoria Land). The reconstructed ice directions and ice dynamic model are comparable to the configurations proposed for the grounded ice expansion within the McMurdo Sound during the Last Glacial Maximum, and they are also consistent with ice-flow patterns previously reconstructed for Pliocene and Pleistocene glacial settings in the region.
\end{abstract}

Keywords: provenance, East Antarctic Ice Sheet, West Antarctic Ice Sheet, Pliocene, Pleistocene

\section{Introduction}

During the austral summer of 2006-2007, the ANDRILL McMurdo Ice Shelf (MIS) project recovered a $1285 \mathrm{~m}$ drill core (AND-1B) from beneath the present-day McMurdo Ice Shelf (Figure 1). The McMurdo Ice Shelf is an extension of the much larger Ross Ice Shelf, the world's largest ice shelf. The Ross Ice Shelf is a major component of the West Antarctic Ice Sheet (WAIS) system and is largely fed by ice streams that drain the WAIS, although its western margin is nourished by outlet glaciers that drain the East Antarctic Ice Sheet (EAIS; Figure 1). Glaciological reconstructions of grounded ice expansion within the Ross Embayment during the Last Glacial Maximum (LGM) (Denton and Hughes, 2000, 2002) suggest an approximately equal contribution of East and West Antarctic sourced ice feeding into grounded ice in the Ross Sea area and previous petrographic studies from the Ross Sea are also suggestive of a relatively equal contribution from each source during the LGM (e.g., Licht et al., 2005).

Paleo-environmental reconstructions based on the AND-1B drill core provide an opportunity to contribute new constraints on the dynamics of the Antarctic ice-sheet system in the Ross Embayment during the Late Cenozoic, as well as to understand the behavior of the EAIS outlet glaciers (Naish et al., 2007, 2009). 

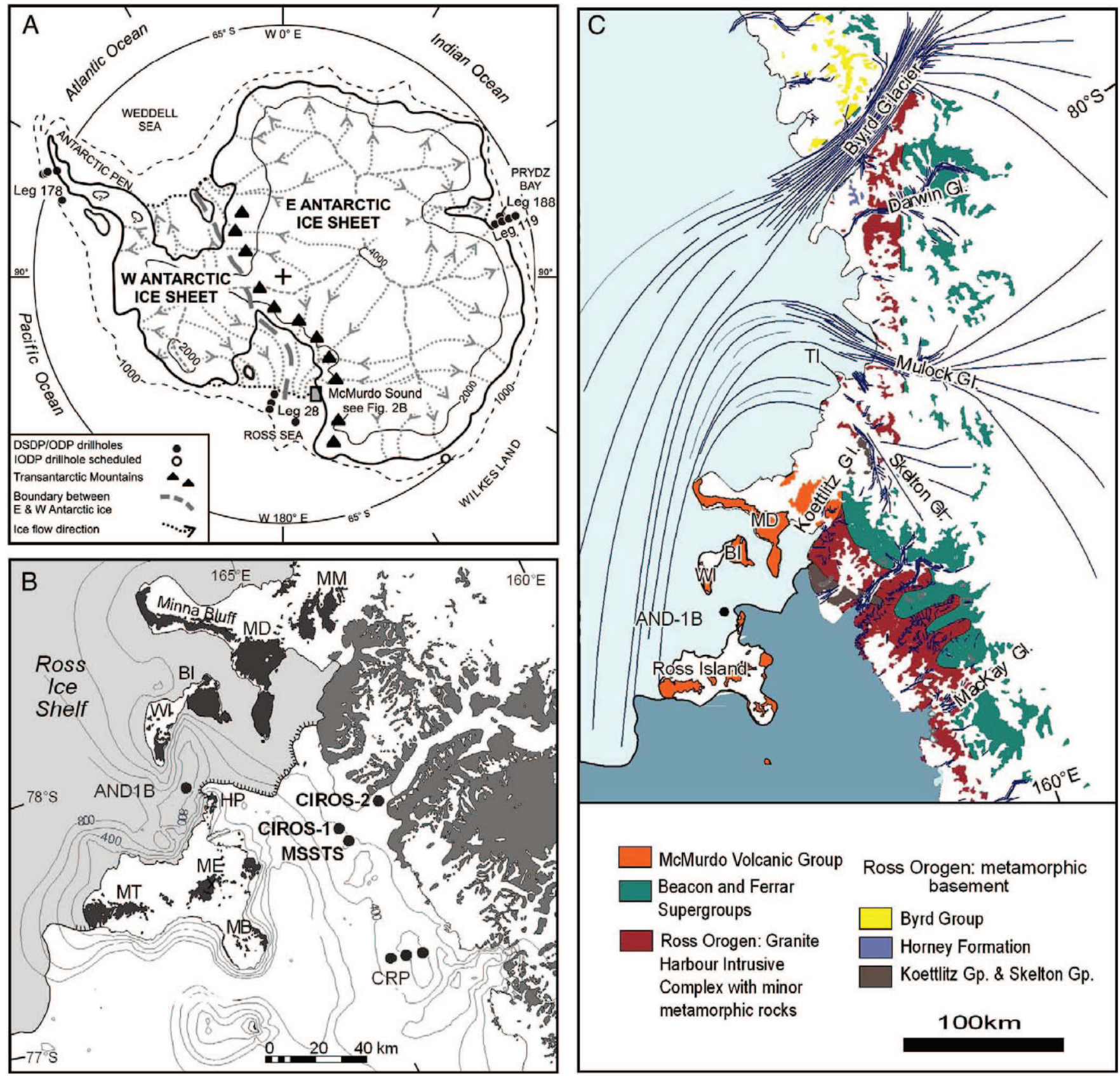

Figure 1. (A) The Antarctic continent with present-day glacial flow lines (after Drewry, 1983; Barrett, 1999), location of McMurdo Sound (boxed) and of geological drill sites on the Antarctic continental shelf. (B) McMurdo Sound region and the AND-1B drill site near Hut Point (HP), as well as previous drill cores (MSSTS, CIROS, and CRP) collected in the region. Abbreviations: BI Black Island; ME Mount Erebus; MB Mount Bird; MD Mount Discovery; MM Mount Morning; MT Mount Terror; and WI White Island. (C) Geological map (after Craddock, 1970; Borg et al., 1989; Carosi et al., 2007). Also shown are present-day glacial flow lines of major outlet glaciers into the Ross Ice Shelf (after Fahnestock et al., 2000; Drewry, 1983) including inferred catchments (based on elevation data of Drewry, 1983). TI = Teall Island.

Preliminary work on basement clasts (Pompilio et al., 2007) qualitatively indicated that the provenance of clasts within massive diamictites interpreted as till in the AND-1B record was consistent with subglacial transport by glacial ice sourced from EAIS outlet glaciers of South Victoria Land (i.e., to the south of the drill site). This compositional evidence indicates that subglacially deposited sediments in AND-1B were the result of large-scale advance of grounded ice, rather than localized glacial advance from Ross Island or outlet glaciers in the McMurdo Sound region (Talarico et al., 2007).

In this paper, we integrate the results of petrological investigations on the sand fraction $(63$ to $500 \mu \mathrm{m})$ and granule- to cobble-sized ( 2 to $256 \mathrm{~mm}$ ) clasts from the uppermost $400 \mathrm{~m}$ of the
AND-1B core, which span in time from Pleistocene to lower Pliocene (ca. 3.5 Ma) (Wilson et al., 2007a).

The study was designed (1) to provide a detailed mineralogical characterization of both the sand and gravel fractions; (2) to outline both long-term and short-term compositional patterns and document compositional variations with respect to sedimentary facies and glacial/interglacial sequence boundaries; and (3) to identify the dominant source areas for glacial debris in AND$1 \mathrm{~B}$ and discuss their implications for ice dynamic models.

The presented data and interpretations help to improve our understanding of the Antarctic ice-sheet evolution through the Plio-Pleistocene and they should play a critical role in providing new useful constraints for both glaciological models based from 
geological studies (e.g., Denton and Hughes, 2000, 2002; Denton and Marchant, 2000), as well as numerical ice-sheets models (Huybrechts, 2002; Ritz et al., 2001; MacAyeal et al., 1996; Hulbe and MacAyeal, 1999).

\section{Geological setting}

Geologic and petrographic data from Cenozoic volcanic centers and outcrops of the Paleozoic to Mesozoic basement in the TAM of South Victoria Land represent an essential data set to identify provenance changes in the AND-1B core (Figure 1). After a short description of the geotectonic setting and evolution of the Ross Sea continental shelf in the McMurdo Sound area, the following sections summarize the most important features of the regional geology in South Victoria Land with a particular focus on those needed for the provenance discussion.

\subsection{Regional geotectonic setting of the AND-1B drill site}

The AND-1B core was recovered from beneath the northwestern corner of the Ross Ice Shelf, and it documents the stratigraphic record of a deep basin that surrounds most of Ross Island (Figure 1). Termed a "flexural moat", this basin is believed to have formed through a combination of localized lithospheric loads emplaced by the development of Ross Island's volcanoes, beginning around $4.6 \mathrm{~m}$.y., superimposed on the regional pattern of rift subsidence (Stern et al., 1991; Horgan et al., 2005). The drill site is situated within the Terror Rift, which lies near the western margin of the larger Victoria Land Basin (Figure 1), one of the three major north-south trending sedimentary basins that form the West Antarctic Rift System. The Victoria Land Basin forms one of several north-south trending troughs on the Ross Sea continental shelf, and these troughs are thought to be the sites of former ice streams that drained the WAIS- and EAIS-sourced outlet glaciers during the Last Glacial Maximum (Hughes, 1977; Denton and Hughes, 2000; Mosola and Anderson, 2006). The Terror Rift is a 70-km-wide structure extending from Mt. Erebus in the south to Mt. Melbourne, ca. $350 \mathrm{~km}$ to the north (e.g., Cooper et al., 1987). In the McMurdo region, the Terror Rift contains ca. $3.5 \mathrm{~km}$ of sediments, accumulated along its central axis since its inception during the Middle Miocene (Henrys et al., 2007).

\subsection{Cenozoic volcanics of the McMurdo Volcanic Group in the vicinity of AND-1B}

The southern and eastern parts of the McMurdo Sound are characterized by the presence of the Cenozoic alkalic Erebus Volcanic Province (Kyle, 1990), extensively cropping out at Ross Island, White Island, Black Island and Mount Discovery-Mount Morning peninsula (Figure 1). Volcanic activity occurred during two main phases, an initial phase (19 to ca. $10 \mathrm{Ma}$ ) characterized by trachytic rocks, and a more voluminous second phase (last 10 m.y.) that is dominated by basanitic to phonolitic sequences (Kyle, 1990). The emergence of these major volcanic centers during deposition of AND-1B has potentially altered past glacial flow-line pathways. The most notable volcanic emergences during the deposition of AND-1B sediments are: Mt. Bird at ca. 4.6 Ma (Wright and Kyle, 1990a), Mt. Terror at ca. $1.75 \mathrm{Ma}$ (Wright and Kyle, 1990b) and Hut Point Peninsula and Mt. Erebus at ca. 1.3 Ma (Esser et al., 2004). White Island contains volcanic deposits as old as 7.65 Ma, yet its northern margin is as young as $0.17 \mathrm{Ma}$ (Cooper et al., 2007).

\subsection{Basement regional geology in South Victoria Land}

The South Victoria Land sector of the Transantarctic Mountains (TAM) lies to the west of the AND-1B drill site, and comprises the western coastline of McMurdo Sound. The basement geology is composed of Late Precambrian to Cambrian metasedimentary clastics and carbonates (Ross Supergroup) and Early Paleozoic granitoids (Granite Harbor Intrusive Complex), which crop out along the coastline of McMurdo Sound (Figure 1). These basement rocks are overlain by the sub-horizontal strata of the Beacon and Ferrar supergroups which are restricted to further inland exposures ca. 25-40 km from the coast (Gunn and Warren, 1962) (Figure 1). The Beacon Supergroup includes sandstones, conglomerates, siltstones and minor coal measures of Devonian to Triassic age, and it is subdivided into a lower quartzose unit (Taylor Group) and an upper carbonaceous-bearing unit (Victoria Group; Harrington, 1965). In Jurassic time, the initiation of the West Antarctic Rift resulted in the basement complex and the Beacon Supergroup being capped by lavas and intruded by dolerite sills and dykes of the Ferrar Supergroup (Kyle et al., 1981).

\subsection{Paleozoic basement rocks to the west and to the south of AND-1B drill site}

There are significant differences in lithological assemblages, metamorphic grade and granitoid fabrics between basement rocks exposed in the Ferrar-Koettlitz glacier (west of AND-1B) and the Skelton-Byrd glacier sector of the TAM (south of AND1B; Figure 1).

To the west of the drill site (i.e., present-day McMurdo Sound), the basement complex consists of upper amphibolite-facies to upper greenschist facies metamorphic rocks of the Koettlitz Group (Cook and Craw, 2001; Talarico et al., 2005). These have been intruded by extensive granitic batholiths of the Granite Harbor Intrusive Complex (Gunn and Warren, 1962; Allibone et al., 1993a). Pure and impure marbles and calc-silicate rocks, interlayered with pelitic schists, paragneisses, amphibolites and minor amphibolitic schists are the main lithologies exposed in the Koettlitz-Ferrar glacier region (Williams et al., 1971; Findlay et al., 1984). The Granite Harbor Intrusive Complex is composed of pre-, syn-, and post-kinematic granitic and subordinate dioritic to gabbroic plutons, plugs, dykes and sills. The Granite Harbor Intrusive Complex also contains a suite of late lamprophyric and felsic dykes which formed as a series of multiple intrusions (Allibone et al., 1993a, 1993b). In the Walcott Glacier region (upper Koettlitz Glacier), many of the plutons include alkaline or alkali-calcic bodies and nepheline syenites, inferred to be associated with extension at 539-531 Ma (Cooper et al., 1997, and references therein).

To the southwest of the Mt. Discovery volcanic centre, the basement exposed in the Skelton Glacier-Mulock Glacier area consists of lower greenschist to lower amphibolite metasediments of the Skelton Group (Gunn and Warren, 1962; Cook and Craw, 2002). Minor alkaline-type quartz syenites and granites are also exposed (Rowell et al., 1993) and include biotite \pm hornblende porphyritic varieties in the Teall Island and Mulock Glacier area (Cottle and Cooper, 2006a; Carosi et al., 2007). The lower greenschist metasediments consist of a variety of lithologies (Skinner, 1982; Cook and Craw, 2002; Cook, 2007) including white to grey metalimestones, coarse-grained marbles, metasandstones (including volcanoclastic varieties), quartzite, polymict metaconglomerate (carrying basaltic, rhyolitic and trachytic pebbles), and slightly deformed flows/sills of trachyte, quartzo-syenite, or basaltic composition (Cook, 2007).

Higher grade metasediments are restricted to limited exposures in the Cook Glacier and Mulock Glacier area (Cook, 2007; Cook and Craw, 2002). These exposures include biotite \pm garnet or hornblende schists (occasionally injected by undeformed granitic veins), cordierite-biotite schists, epidote-biotite-actinolite schists, and diopside \pm scapolite granofelses. Exposures to the south between Mulock and Darwin glaciers are dominated by granitoids (mainly post-tectonic granodiorites such as the Cooper Granodiorite, but also less extensive foliated porphyritic monzogranite) and minor mafic intrusions (e.g., Fontaine Pluton; Cottle and Cooper, 2006b). Even further to the south, in the Britannia Range (between Darwin and Byrd glaciers), mediumto high-grade metasediments (banded gneisses, schists with Casilicate layers, migmatites and minor amphibolite, and marbles) and variably deformed (foliated to mylonitic) granitoids are common (Carosi et al., 2007). 


\section{AND-1B core: chronostratigraphy and sequence strati-} graphic framework

Based on major changes in lithology recognized during the initial phase of core characterization, the uppermost $459 \mathrm{~m}$ of AND-1B core was divided into four lithostratigraphic subunits (LSU; Krissek et al., 2007). LSU 4.1 (459 to 383 meters below the sea floor, mbsf) consists of thick (up to ca. $90 \mathrm{~m}$ ) diatomite intervals interbedded by volcanic-rich to volcanic-bearing diamictite and mudstone/sandstone deposits. Overlying this, LSU 3.1, $3.2,3.3,3.4,3.5$ and 3.6 (383 to $147 \mathrm{mbsf}$ ) largely consist of alternating beds (10's $\mathrm{m}$ thick) of diatomite and diamictite. LSU 2.1, 2.2, 2.3 and 2.4 (147 to $82.7 \mathrm{mbsf}$ ) comprise beds of diamictite interlayered with volcanic sandstone and mudstone/diatomites. The uppermost $82.7 \mathrm{~m}$ (LSU 1.1) consists of diamictite (10's m thick) occasionally interbedded by thin (ca. $1 \mathrm{~m}$ thick) beds of mudstone/sandstone.

A well-constrained chronology (Wilson et al., 2007a), based on single crystal ${ }^{40} \mathrm{Ar} /{ }^{39} \mathrm{Ar}$ ages, microfossil biostratigraphy and magnetostratigraphy, indicates that the upper $440 \mathrm{~m}$ of AND-1B can be divided into four chronostratigraphic windows: (1) the mid-Pliocene (ca. 3.6-3.2 Ma) between 440 and 280 mbsf; (2) the Late-Pliocene (ca. 2.75-2.35 Ma) between 253 and 150 mbsf; (3) a relatively discontinuous section during the Early Pleistocene (150-82.7 mbsf); and (4) the Late Pleistocene (ca. 0.78-0.1 Ma) between 82.7 and 20 mbsf.

The paleoclimatic significance of this record is important as it is the first expanded stratigraphic drill core from the Antarctic margin (and below an ice shelf) that provides a direct and high-resolution record into the evolution of the Antarctic cryosphere from a period of relative global warmth in the mid-Pliocene through a marked cooling step in deep sea oxygen isotope records ca. 3 to 2.5 million years ago, to the development of the present cold polar Antarctic thermal regime during the last ca. 1 million years (Naish et al., 2007, 2008; McKay et al., 2009) (Figure 2).

In the upper $400 \mathrm{~m}$ of AND-1B, two distinct styles of these packages are identified, and have been classified as "sequence motifs", each representing distinct styles of glacial-interglacial advance and retreat under a different climatic/glacial regime. Motif 1 occurs in the Late Pleistocene interval of AND-1B (0-82.7 mbsf) and is dominated by thick subglacial diamictite, deposited during glacial advance, with occasional thin interbeds of sparsely- to non-fossiliferous mudstone that marks an ice shelf setting during interglacial maxima. The near absence of subglacial melt-water facies suggests that advance and retreat occurred under cold, polar conditions. Motif 2 (Pliocene) comprises subglacial to glacimarine diamictite overlain by thin, proglacial deposits and capped with substantial beds of diatom-bearing mudstone or diatomite formed under open-marine conditions. The marked fluctuation between ice-grounded and open-marine phases reflects advance and retreat under conditions warmer than Motif 1, a general absence of prolonged ice shelf conditions during interglacials, but still without significant subglacial melt water. Motif 2 cycles are interpreted as representing a gradual up-core transition from a subpolar in the midPliocene to more polar glacial regime by the Late Pliocene/Early Pleistocene (McKay et al., 2009).

\section{Methods}

\subsection{Gravel fraction}

Sampling, macroscopic observations and preliminary petrographical analyses were performed following the procedures for the Cape Roberts Project (CRP)- 1 core (Cape Roberts Science Team, 1998a, 1998b) and the clast distribution was determined following the same methodology adopted in CRP-2/2A
(Cape Roberts Science Team, 1999). Identification of six major lithological groups (volcanic rocks, intrusive rocks, metamorphic rocks, sedimentary rocks, dolerites, and quartz) was based on distinctive macroscopic features, and confirmed by microscopic analysis on selected clasts (e.g., Pompilio et al., 2007; Table 1). The core was split in two to create a flat face, and the composition, dimension and shape were determined for clasts visible in the cut surface of the working-half core, with an average diameter exceeding $2 \mathrm{~mm}$ (i.e., granule to cobble). The core diameter was $83 \mathrm{~mm}$ between 61 and $244 \mathrm{mbsf}$; while between 0 and 61 mbsf, and 244 and 701 mbsf, core diameter was $61 \mathrm{~mm}$.

Data processing involved summation of all clasts from the different compositional groups per $10 \mathrm{~cm}$ and per 1 moving meter. The term "basement clast" is used here to refer to extrabasinal clasts sourced from the pre-Devonian crystalline basement presently exposed in the TAM west and south of the AND-1B drill site. The Ferrar and Beacon supergroups are excluded from this class. Only core intervals with high number of clasts $(>10$ per moving meter) were considered for analysis and discussion of clast distribution trends.

Identification of source rock units for basement pebbles was based on (1) detailed petrographical investigations on all cobble or pebbles of appropriate size to allow a complete mineralogical and textural analysis using a standard thin section, (2) a sampleto-sample comparison of all investigated clasts with c. 1500 samples collected from c. 70 outcrops in the SVL (stored at the Core Repository of the Museo Nazionale dell' Antartide, Siena, Italy).

In most cases provenance inferences were constrained using groups of pebbles of several basement rock types (from 2 to 5 ) occurring within short core intervals (i.e., $<1 \mathrm{~m}$ thick) and indicating a provenance from compositionally similar lithological assemblages which are diagnostic of specific and restricted areas in SVL.

\subsection{Sand fraction}

A total of 51 thin sections were analyzed from the sand fraction $(63-500 \mu \mathrm{m})$ from the upper $400 \mathrm{~m}$ of AND-1B, mainly from stratified or massive diamictites, sandstone or sand-bearing mudstones. Samples were impregnated with epoxy resin and cut into unstained and uncovered thin sections. Following preparation of the grain mount thin sections, modal petrographic analysis (300 grain point count) for the $63-500 \mu \mathrm{m}$ fraction was undertaken.

\section{Results}

The results of our petrological investigations are presented in a series of diagrams (Figures 2, 3, \& 5) and are discussed at two different scales of analysis: (1) clast variability at a 1-m resolution that is sufficient enough to show the internal clast variability occurring in each lithofacies, and provides insight into the compositional variability through individual glacial/interglacial cycles; and (2) with respect to compositional changes within individual lithological facies (massive diamictites, massive mudstones, diatomites, mudstones with common or dispersed clasts) in order to describe the long-term compositional variability in the upper $400 \mathrm{~m}$ of AND-1B.

Emphasis is placed on the Plio-Pleistocene section of uppermost $200 \mathrm{~m}$ of AND-1B, where glacial/interglacial sequences are well defined (a total of 18 cycles), and corresponds with the change in cycle motifs from Motif 2 (below $82.7 \mathrm{mbsf}$ ) and Motif 1 (above 82.7 mbsf) which is interpreted by McKay et al. (2009) as representing the final transition to the modern-day style of cold polar ice sheets.

Our petrological data on both gravel and sand fractions provides key evidence for the identification of the most likely 


\begin{tabular}{|c|c|c|c|c|c|c|c|c|c|}
\hline \multirow{3}{*}{ 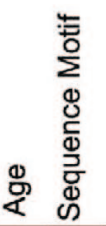 } & \multirow{3}{*}{ 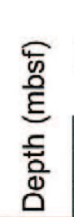 } & \multicolumn{2}{|l|}{ Lithology } & \multirow[t]{2}{*}{$\begin{array}{l}\text { Glacial } \\
\text { proximity }\end{array}$} & \multicolumn{2}{|c|}{ Clast Provenance } & \multirow{2}{*}{$\begin{array}{c}\text { Clast } \\
\text { abundance } \\
\text { (count/m) }\end{array}$} & \multirow{2}{*}{$\begin{array}{c}\text { Qr:Qa } \\
\text { (sand } \\
\text { fraction) }\end{array}$} & \multirow{2}{*}{$\begin{array}{l}\mathrm{Q}_{\mathrm{roT}}(\%) \\
\text { (sand } \\
\text { fraction) }\end{array}$} \\
\hline & & Mud & $\begin{array}{c}{ }^{40} \mathrm{Ar} /{ }^{39} \mathrm{Ar} \\
\text { age }\end{array}$ & & $\begin{array}{l}\square \text { Intrusives } \\
\square \text { Quartz }\end{array}$ & $\begin{array}{l}\square \text { Sedimentary } \\
\square \text { Volcanic }\end{array}$ & & & \\
\hline & & $\begin{array}{l}\text { Sand } \\
\text { Gravel }\end{array}$ & & ـ ـ & $\square$ Dolerite & $\square$ Metamorphic & $\begin{array}{lll}0 & 100 & 200 \\
10 & \end{array}$ & $00.2,0,6,1.0$ & $\begin{array}{lll}0 & 25 \quad 50 \\
\end{array}$ \\
\hline
\end{tabular}

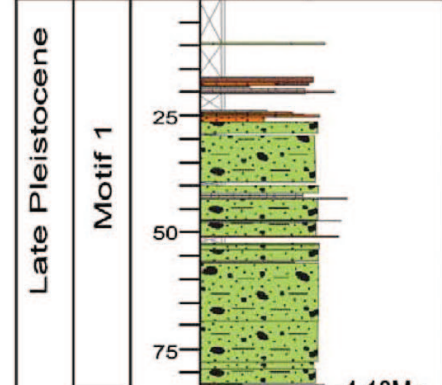

0
$\frac{2}{0}$
0
0
$\frac{0}{0}$
$\frac{0}{0}$
$\frac{1}{0}$
$\frac{2}{2}$
$\frac{1}{\pi}$
$\frac{1}{4}$

(1)


Table 1. Distribution of different type of basement clasts in the uppermost $400 \mathrm{~m}$ of AND-1B.

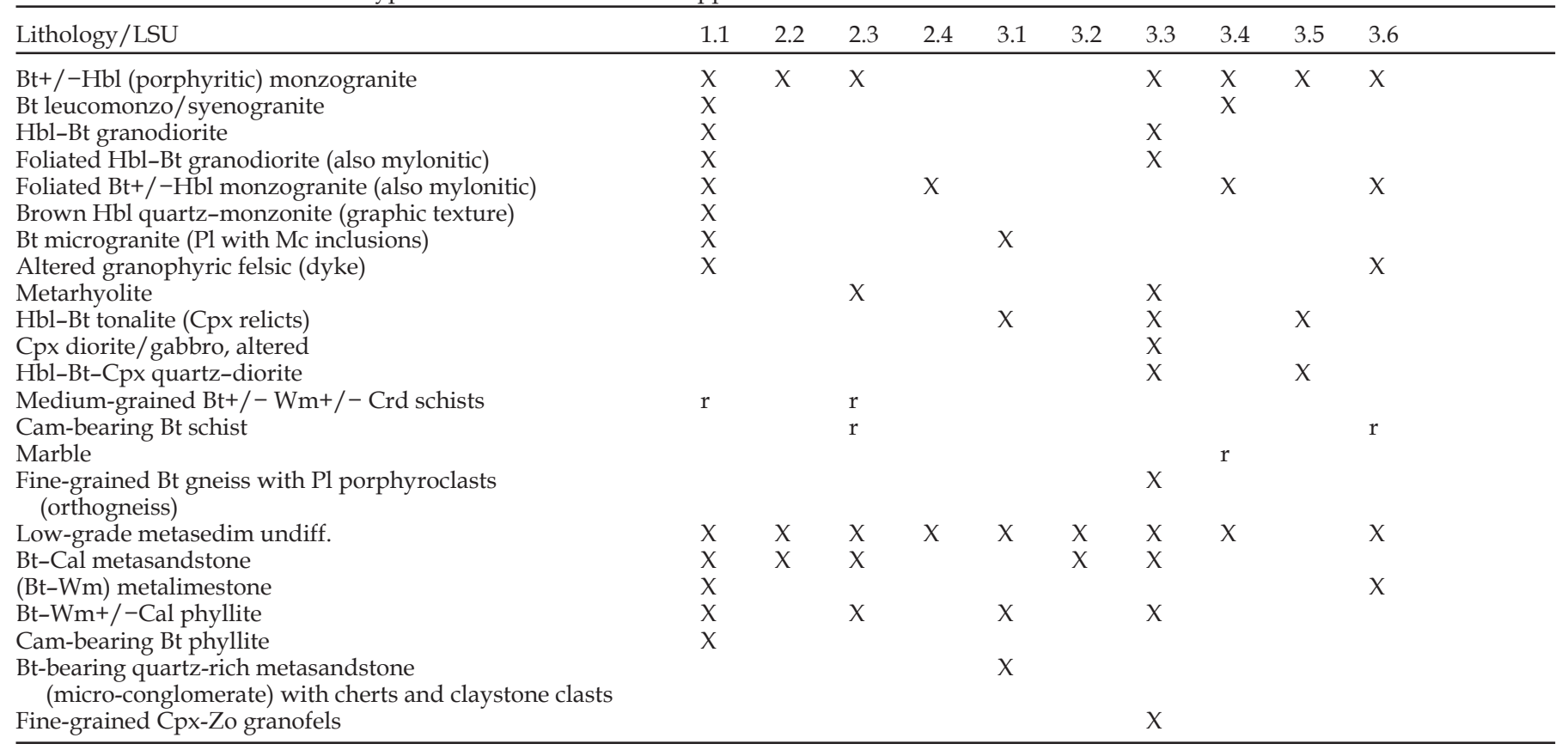

Note: $r=$ rare and $X=$ frequent. Mineral abbreviations after Kretz (1983).

LSU: lithostratigraphic subunits after Krissek et al. (2007).

source units and regions, and a specific section is devoted to the description of the main key lithologies and the related provenance constraints.

\subsection{Lithologies observed in the sand and gravel fractions}

In the gravel fraction, a total of 24,145 clasts were counted and categorized into six main lithological groups. Their main features and clast dimensions can be summarized as follows:

(1) Volcanic rocks: this group includes a variety of aphyric to porphyritic varieties, some vesicular and/or amygdale-bearing, ranging in composition from mafic to intermediate and felsic. Volcanic clasts are mostly granules to small- and medium-sized pebbles.

(2) Intrusive rocks: these consist mainly of biotite with or without hornblende granitoids (e.g., granites, syenogranites, and granodiorites) showing either isotropic fabrics or foliated to strongly mylonitic fabrics, with minor occurrence of deformed felsic porphyries and gabbroids; they are mostly represented within the pebble and small cobble class.

(3) Metamorphic rocks: a variety of low-grade metasedimentary rocks of various origin (metalimestones, phyllites, and metasandstones) with rare occurrences of biotite and cordierite, biotite-actinolite schists and marble, are represented in this class. All of these rock types occur as granule, pebbles and cobbles.

(4) Sedimentary rocks: these include at least two major lithological types: (a) quartz-arenites, likely sourced from the Beacon Supergroup, and (b) intraformational clasts consisting of poorly- to moderately-sorted sandstone with granulegrade clasts (reworked diamictites) and grey to black mudstone and minor sandstones. These clasts mainly belong to the granule and small-pebble classes.

(5) Dolerites: generally fine- or medium-grained with textural and mineralogical similarities to the Ferrar Dolerite. They display variable alteration and occur as granule to subrounded pebbles and cobbles.

(6) Quartz: occurs as granules or small pebbles, some of them carrying minor micas, and are most likely fragments of coarse-grained granitoids.

In the sand fraction, groupings for modal analysis were as follows:

(1) Volcanic glass and lithics: volcanic lithics vary from unweathered, angular basaltic groundmass with K-feldspar, plagioclase, olivine or pyroxene phenocrysts to reworked and heavily weathered volcanic lithic grains displaying significant quantities of clay minerals enclosing feldspars, olivine and pyroxenes. The volcanic lithics are all inferred to be sourced from the McMurdo Volcanic Group, although no distinction of individual volcanic centers (i.e., Ross Island, Black Island) is made. Volcanic glass varied from colorless/light brown to red brown, ranged from angular to subrounded, and was often highly vesicular with rare olivine/ plagioclase phenocrysts.

(2) Plagioclase: angular to rounded grains, with a tabular form and cleavage at ca. $90^{\circ}$, multiple twinning, and commonly, local alteration to sericite.

(3) Feldspar: angular to rounded grains, with evidence of cleavage and commonly displaying significant alteration (visible in plain polarized light). Microcline with cross hatched twinning, indicative of a granitic source was also noted.

(4) Quartz: varies from angular to well-rounded. Most grains are mono-crystalline with straight to strong undulose extinction. Some grains have fluid inclusions. Smaller grains of quartz lacking distinguishing features may have been identified as feldspar. Polycrystalline quartz grains were also included in this group. Quartz grains were subdivided into four sub-categories (angular, rounded, rounded with overgrowths, and polycrystalline quartz). Rounded to well-rounded quartz with overgrowths is inferred to be derived from Devonian Beacon Supergroup sediments (Korsch, 1974). Polycrystalline quartz commonly has a foliated texture and is indicative of basement metasediments or syn-tectonic granites.

(5) Sedimentary grains: range from quartz-arenite to arkose lithics, mostly derived from the Beacon Supergroup.

(6) Metamorphic grains: metamorphic sand grains are rare, but 

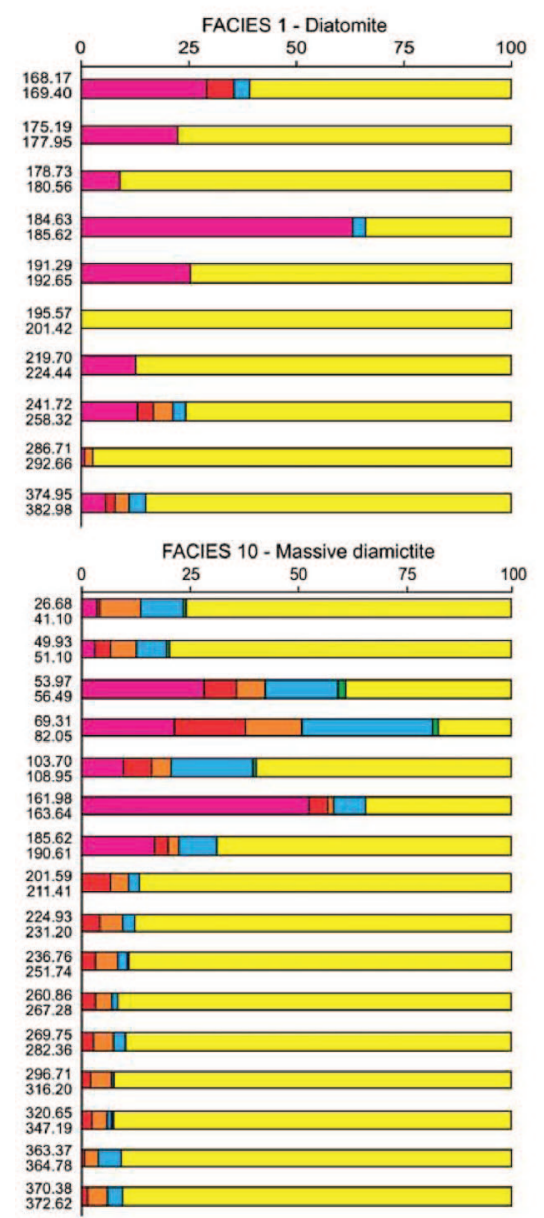
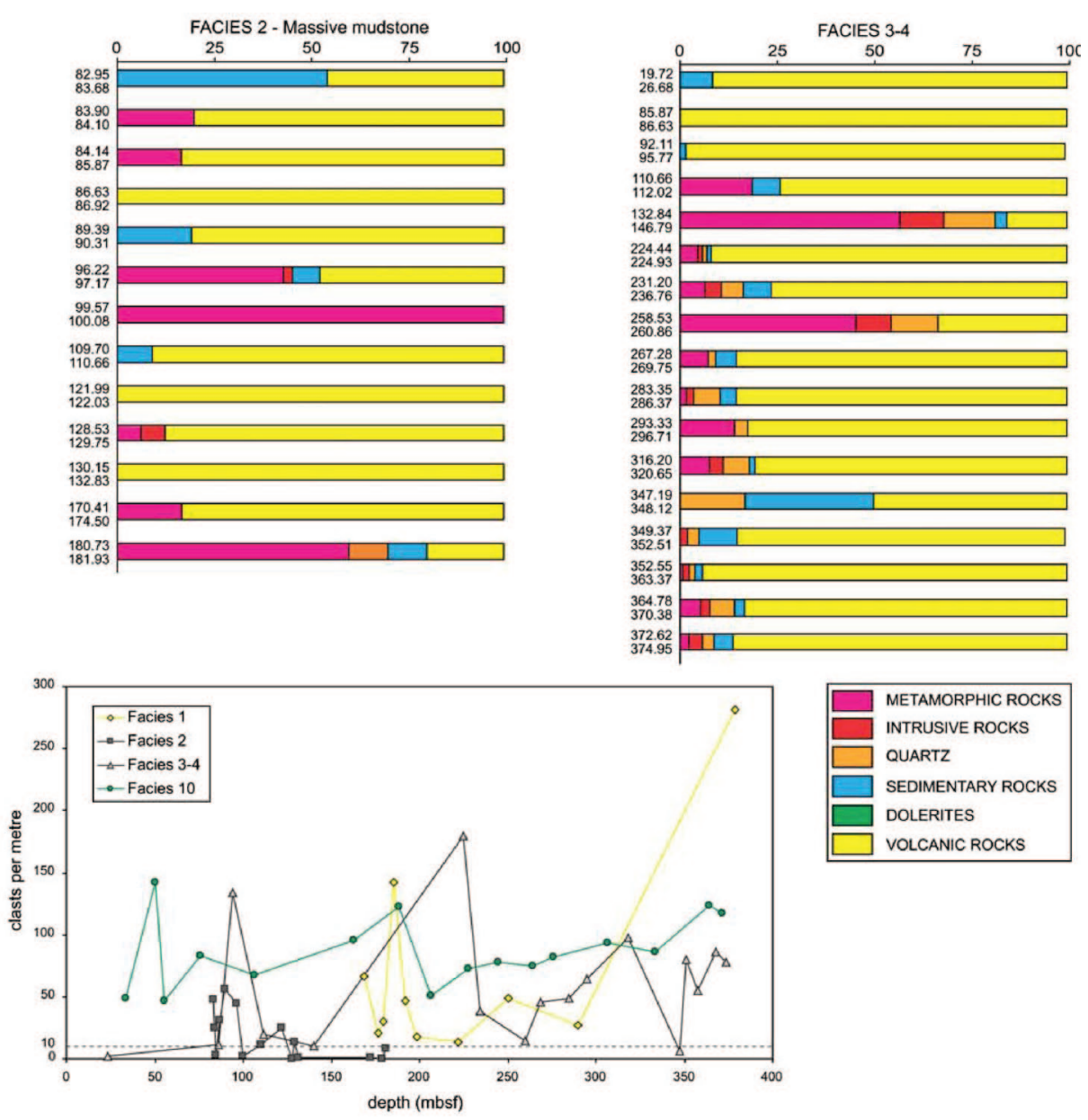

Figure 3. Down-core compositional variations in the gravel fraction in the uppermost $400 \mathrm{~m}$ of AND-1B core with respect to the hosting facies. The diagrams show the content of clasts in the different intervals for each facies (facies group from Krissek et al., 2007).

when present were mostly low-grade metasediments (e.g., phyllites or metasandstones).

(7) Heavy and other minerals: many of the heavy minerals were broken grains that lacked distinguishable features although pyroxenes, amphiboles and biotite were noted and counted separately, and subsequently placed into this grouping. Also noted (albeit in low abundance) was inverted pigeonite, a pyroxene that is indicative of the Ferrar Supergroup and displays distinctive exsolution lamellae in a chevron type pattern. Pigeonite is not observed in pyroxenes derived from the McMurdo Volcanic Group (Smellie, 1998).

\subsection{Petrography of basement clasts and provenance inferences}

Clast logging and sampling in AND-1B indicate that basement clasts are highly variable throughout the cored interval and that pebble- to cobble-sized clasts consist of a wide range of lithological types (Pompilio et al., 2007). In the uppermost 400 m, 114 samples, representative of all lithological types, were collected and investigated using a petrological microscope. The distribution of identified rock types for each LSU is reported in Table 1.

\subsubsection{Metasediments}

Metasedimentary rocks are identified by a wide range of protoliths. Biotite \pm calcite $\pm \mathrm{Ca}$-amphibole metasandstones (Figure $4 \mathrm{~A}, \mathrm{~B}, \mathrm{C})$, biotite slates/phyllites, metavolcanoclastic sandstones and conglomerate, and metalimestones (Figure 4D) are characterized by decussate, spotted microstructures diagnostic of contact metamorphism, or more often by oriented fabrics indicative of syn-tectonic recrystallizations; in these rocks, mineral assemblages are indicative of biotite-zone (greenschist facies/lowgrade) metamorphic conditions. Other metamorphic lithologies show more restricted occurrences and are represented by rare clasts (Table 1). They include actinolite-biotite schists, cordierite-bearing biotite-muscovite schists, and marbles, all indicative of higher grade conditions, with mineral paragenesis diagnostic of lower amphibolite-low pressure facies conditions.

The low-grade metasediments are scattered throughout the core, usually mixed with undeformed or foliated granitoids and metarhyolites (Table 1).

\subsubsection{Granitoids and metarhyolites}

Granitoid pebbles consist of dominant isotropic or foliated biotite granites and biotite-hornblende syenogranites, monzogranites and granodiorites. Minor lithologies include: biotitehornblende tonalite, isotropic or foliated biotite-hornblende quartzo-diorite and gabbro, biotite-hornblende alkali feldspar granite, mylonitic or foliated muscovite-bearing granite and felsic igneous rocks possibly derived from dyke swarms (e.g., microgranites, leucogranites, and granophyres). Microscopic examination revealed that all granitoid types show a variably developed alteration; allanite, zircon/monazite, apatite and titanite were found to be the most common accessory minerals in most samples. Most importantly, granitoid fabrics were found to be highly variable including both isotropic, hypidiomorphic and strongly heterogranular textures (Figure 4E) and variably foliated to mylonitic fabrics indicative of syn- and post-emplacement deformation. In metarhyolite clasts, phenocrysts of 

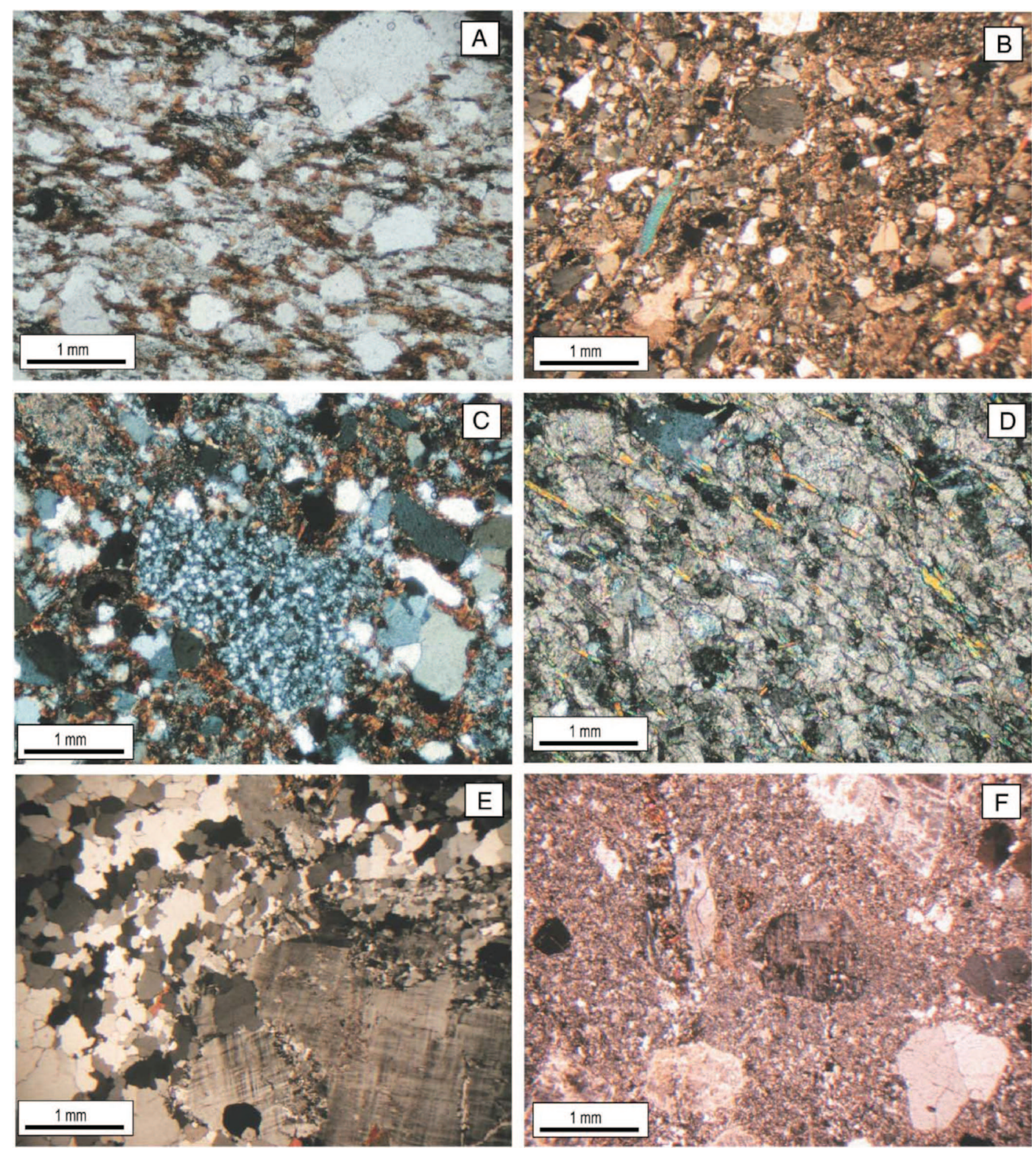

Figure 4. Representative basement clasts, all considered as diagnostic lithologies to identify the Skelton-Mulock glacier region as the source region for basement clasts throughout the Plio-Pleistocene AND-1B core section. (A) Biotite-bearing metasandstone (20.25 mbsf in massive diamictite; plane-polarized light). (B) Biotite-calcite bearing metasandstone with detrital flakes of muscovite (50.45 mbsf in massive diamictite; crossed polarizers). (C) Biotite-bearing metasandstone with chert granules (61.03 mbsf in massive diamictite; crossed polarizers). (D) Muscovite-bearing metalimestone (149.96 mbsf in stratified diamictite; crossed polarizers). (E) Biotite-bearing heterogranular monzogranite. Microcline phenocrystals are set in a fine-grained granular matrix (65.50 mbsf in massive diamictite; crossed polarizers). (F) Metarhyolite: quartz and microcline phenocrystals are set in a recrystallized groundmass with neoblastic biotite (101.84 mbsf in massive diamictite; crossed polarizers).

quartz and microcline are set within a recrystallized groundmass composed of neoblastic feldspars associated to randomly oriented biotite flakes (Figure $4 \mathrm{~F}$ ). In some samples the fabric is mylonitic. In the gravel fraction, as in CRP and CIROS cores (Talarico and Sandroni, 1998; Talarico et al., 2000; Sandroni and
Talarico, 2001, 2004, 2006), the granitoid pebbles can be closely match to source rock units belonging to the Cambro-Ordovician Granite Harbor Igneous Complex, which is the dominant component in the Ross Orogen in South Victoria Land (Gunn and Warren, 1962; Allibone et al., 1993a, 1993b). 


\subsubsection{Beacon sandstone}

In the sand fraction, as it is absent in the McMurdo Volcanic Group (Kyle, 1990), quartz can be considered as the most distinctive indicator of the Transantarctic Mountains provenance. Rounded quartz with or without overgrowths can be directly attributed to Devonian Taylor Group (Beacon Supergroup) sandstones (Korsch, 1974), while metamorphically shocked quartz is likely attributed to metasediments of the Ross Orogen or syntectonic plutons of the Granite Harbor Intrusive Complex (Gunn and Warren, 1962). Angular quartz can be attributed to any of these groups.

\subsubsection{Provenance identification based on lithologies present}

The petrographical features of basement clasts and some mineralogical characteristics of the sand fraction provide important evidence to identify the potential source rock units and provenance regions for the supply of glacial debris to the AND-1B drill-site area in the Late Pliocene-Pleistocene time. The occurrence in AND-1B of pebbles of phyllites and lowgrade metasandstone scattered throughout the core is noteworthy as the on-shore exposures of these rocks are rather limited and restricted to areas of the Skelton Group (Grindley and Warren, 1964) between the Skelton and Mulock glaciers, about $100 \mathrm{~km}$ southwest of the AND-1B drill site (Figure 1). Mediumgrade metamorphic rocks such as coarse-grained marbles are known to be common rock types in the amphibolite-facies Koettlitz Group between Koettlitz and Mackay glaciers (Grindley and Warren, 1964; Williams et al., 1971; Findlay et al., 1984; Allibone, 1992; Turnbull et al., 1994). However outcrops of similar marbles, associated to the rare biotite-cordierite schist found in the AND-1B core, are reported only in areas where the lowgrade metasediments are volumetrically dominant such as the Cook Glacier (Skelton Glacier area) and the lower Mulock Glacier (Cook and Craw, 2002).

As a whole, there is a very close petrographical similarity among AND-1B clasts and various lithologies reported in the Skelton-Mulock glacier area, where low-grade metasediments are exclusive in most outcrops. Importantly, the occurrence of several basement lithologies (e.g., usually more than two) within a short core interval (i.e., $<1 \mathrm{~m}$ thick) indicate well-defined rock assemblages that mirror restricted outcrop areas: e.g., volcanoclastics, metalimestones, metarhyolites and strongly heterogranular granitoids (e.g., an assemblage typical of LSU 1 in the upper $82.7 \mathrm{~m}$ of AND-1B; Table 1) closely match a compositionally similar assemblage that was recognized and mapped at Teall Island-Mulock Glacier area and elsewhere in the Cook Glacier area (Cook, 1997, 2007; Cook and Craw, 2002; Carosi et al., 2007).

Low-grade metasediments were also reported on the divide between Koettlitz Glacier and Skelton Glacier (Mt. Cock area). However, the lithological variability of these metasediments is much more limited with dominant metagreywackes and epidote-rich metapelite (Cook, 1997), a facies yet not found in the AND-1B core. Moreover, a provenance from this area, or paleovalleys located further to the north (e.g., Blue and Ferrar glaciers), is not consistent with the absence of medium-grade rocks (including distinctive sugar-texture marbles, garnet-bearing paragneisses, hornblende-biotite schists with diopside porphyroblasts) that are the dominant basement lithologies in the Koettlitz Glacier, Blue Glacier or Ferrar Glacier catchment areas.

\subsection{Long-term compositional variability}

Volcanic rocks, sedimentary rocks, quartz, metamorphic rocks and granitoids are ubiquitous throughout the upper $400 \mathrm{~m}$ of the AND-1B core, with volcanic rocks constituting the dominant lithology, although in diamictite facies TAM basement lithologies constitute between 10 and $20 \%$ of the total clast content (Figure 2). The exception to this is the upper $82.7 \mathrm{~m}$ (LSU 1.1) which is dominated by diamictite deposits, and basement clasts of various composition and sedimentary clasts are the dominant lithologies. In this core section, the abundance of TAM basement lithologies commonly exceeds $50 \%$, although there is a notable decrease in the upper part of this interval (e.g., 54-25 mbsf). This trend is mirrored in the sand-fraction results, whereby diamictite facies tend to contain abundant Transantarctic Mountain detritus, whereas open-marine diatomites are rich in volcanic detritus. Figure 2 shows the down-core variability of volcanic grains relative to facies. The sand fractions in the diatomite samples (yellow data points) contain ca. $50 \%$ or more volcanic glass and lithics, whereas diamictite samples (green data points), with a few exceptions, contain less than $25 \%$ volcanic lithics or glass. Mudstone and mudstone with dispersed clasts change composition down core, with samples above $150 \mathrm{mbsf}$ generally containing $>25 \%$ volcanic grains, well above the base level for the diamictite samples.

Between 400 and 150 mbsf (mid-Pliocene to Late Pliocene), the most prominent trend among basement clasts is shown by an up-core increase in metamorphic clasts. The proportion of sedimentary clasts (mostly Beacon Supergroup) is mostly $<5 \%$ between 400 and 150 mbsf, and only rarely exceeds $10 \%$. However above 150 mbsf, Beacon Supergroup clasts commonly exceed $10 \%$ in diamictite facies and can represent up to the $80 \%$ of the total clast assemblage. Dolerite shows a restricted distribution throughout AND-1B, yet clasts are consistently more abundant in the upper $80 \mathrm{~m}$ of AND-1B. This increase in Beacon Supergroup and dolerite clasts in the Late Pleistocene interval of AND-1B (80-0 mbsf) is mirrored by a significant and consistent increase in rounded quartz (and quartz with diagenetic overgrowths) in the sand fraction. Below 150 mbsf, abundances are generally $<25 \%$ and more closely mirror abundances in the diamictite facies. Due to the dominance of feldspar and volcanic sand grains in many of the samples, the majority of mineral assemblages have abundances of $<5 \%$, making it difficult to identify statistically significant trends from most mineral or lithic groups. However, quartz usually constitutes between ca. $10 \%$ and $30 \%$ in the diamictite facies and Figure 2 shows a depth plot for the ratio of Qr (rounded quartz with overgrowths and rounded quartz) to Qa (angular quartz), which allows for identification of provenance signal that is not affected by the abundance of volcanic grains. Above $80 \mathrm{mbsf}$, the ratio in all but one diamictite sample exceeds 0.2 , while below $80 \mathrm{mbsf}$ it never exceeds 0.2 in the diamictite samples. The significantly higher proportion of rounded quartz grains (many of which display overgrowths) above ca. $80 \mathrm{mbsf}$, indicates an increase contribution from Devonian Beacon Supergroup (Taylor Group) sediments. As Ferrar Dolerite outcrops as sills that intrude Beacon Supergroup sediments in the Transantarctic Mountains (Tingey, 1991), an increase in Beacon Supergroup is expected to be associated with an increase in Ferrar Dolerite clasts, as is the case in the upper $80 \mathrm{~m}$ of AND-1B. Dolerite lithics and inverted pigeonite, a pyroxene characteristic of the Ferrar Dolerite, were noted in the sand fraction, but were rare $(<2.3 \%)$ in all samples, and no statistically significant trend is observed. The abundance of quartz in sand fraction from the diamictite facies of the upper $80 \mathrm{~m}$ averages ca. $30 \%$. This value is consistent with quartz abundances from LGM (and retreat-phase) diamictites from the McMurdo region, which range between 30 and $37 \%$ for cores immediately north of Ross Island (Licht et al., 2005) and from beneath the McMurdo Ice Shelf (McKay et al., 2008).

Reworked diamictites and other intrabasinal clasts can represent up to $80 \%$ of the sedimentary clasts population in LSU 2.1 , ca. $20 \%$ in LSU 1.1 and ca. $10 \%$ in LSU 2.1, whereas Beacon sandstone are the dominant variety in all the other LSUs.

\subsection{Clast compositional variability with respect to the main lithological facies}

Clast compositional variability with respect to the main lithological facies in the uppermost $400 \mathrm{~m}$ is shown in Figure 3. In the sand fraction, the results and the provenance of any given 
sample are highly facies dependent as was noted in McKay et al. (2008). Nevertheless, there is a general agreement between the sand-fraction main compositional patterns (Figure 2) and the gravel-fraction data, particularly when the latter are analyzed in terms of shorter core intervals, such as the core sections consisting of a single sedimentary facies (Figure 3).

Among the diamictite facies, only massive diamictite facies was considered, the stratified variety being represented in core intervals too short (a few dm thick) in order to have a sufficiently high number of clasts to describe their composition. Other considered facies include: massive mudstone (restricted in occurrence to the section between ca. 75 and $180 \mathrm{mbsf}$ ), diatomite (occurring below ca. 170 mbsf and including the two varieties: a: lacking terrigenous component; and b: terrigenous-bearing), and the mudstone facies dominated assemblage (mudstone with dispersed or common clasts, or with variable interstratified sandstone) (corresponding to Facies 3 and 4 in Krissek et al., 2007), at places associated to minor volcanic sandstone or stratified diamictite (6 V and 9 in Krissek et al., 2007).

The number of clasts per meter length throughout the investigated core section is highly variable, ranging from 10 counts per meter in the facies dominated by mudstone, sandstone or diatomite facies to values in the range of ca. 50-90 (maximum 220) counts per meter in massive diamictite intervals (Figure 2).

Similar to massive diamictite, mudstone dominated facies (Facies 3 and 4) show variable clast contents, but with generally high values (38 to 180 clasts/m) apart from intervals at ca. 25, 85,110 , and 260 mbsf. Intervals above 140 mbsf lack of quartz and granite clasts, which are ubiquitous in the lower section.

In diatomite facies, clast abundance ranges from 14 to 281 clasts/m, with volcanic clasts (often pyroclastics) being the major contributor, with the exception of an interval at ca. 180 mbsf where metamorphic clasts exceed 60\%. Quartz and granite are absent in most intervals (accompanied by minor intraclasts and Beacon sandstone clasts they are restricted to ca. 170, 250, 290 and 375 mbsf) and dolerite clasts were never found.

Clast variability in massive mudstones facies is characterized by the lowest clast contents (0-48 clasts $/ \mathrm{m})$. Assemblages are generally dominated by a high volcanic component (ca. 80$100 \%$ ) with minor metamorphic or sedimentary clasts and/or intrusive rocks. Exceptions are represented by intervals at ca. 83, 97, 100 and 181 mbsf (Figure 3), and in most cases they correspond to intervals where the very low clasts number per meter $(<10)$ does not allow a confident quantitative assessment of lithological proportions.

\subsection{Glacial to interglacial variability}

Changes in provenance are also related to changes in sedimentary processes over the glacial/interglacial cycle, and we use the sequence stratigraphic model developed by Krissek et al. (2007) and McKay et al. (2009) to discuss these changes. A total of 18 cycles are identified in the upper $200 \mathrm{~m}$ of AND-1B, and these have each been assigned a sequence number and are discussed below (see Figure 5). Sand-grain compositional data from discrete samples and clast distribution patterns at $1 \mathrm{~m}$ scale intervals allow a high resolution analyses of compositional variability through individual glacial/interglacial cycles in the uppermost $200 \mathrm{~m}$ of the AND-1B core (Figure 5). The gravelfraction data indicate that glacial minima intervals are at places characterized by absent or very low numbers of clasts (e.g., in Sequences 2, 13, 14, 16), but glacial minima intervals with a number of clasts $>11 / \mathrm{m}$ are also common (e.g., Sequence 10) as well as up-core increases of the clast content in the overlying proglacial sediments (e.g., Sequences 10 and 15).
In the sand fraction, petrology results highlight provenance variability through most individual glacial/interglacial cycles. However, not all glacial minima contain the same provenance signal. For example, the glacial minima facies (at ca. $25 \mathrm{mbsf}$ ) in Sequence 2 are characterized almost entirely by volcanic glass before passing upwards in proglacial mudstone and sandstone that have a similar proportion of quartz as the overlying diamictite in Sequence 1. The glacial minima facies in Sequence 3 contains quartz throughout, and although there is an increase in volcanic lithics and glass, it is not the dominant provenance signal, suggesting a relatively closer proximity to the ice sheet grounding line throughout the glacial minima, or the reworking of older deposits by mass flow processes.

In the gravel fraction, compositions appear to be much less variable. Apart from Sequences 11 and 17, where metamorphic clasts form the prevailing or exclusive component, clast compositions from all glacial minima intervals show a dominant volcanic component comprising dominant glassy lapilli, very angular to sub-rounded ash shards and felsic or intermediate lavas (Pompilio et al., 2007). In these intervals, granule- to pebble-sized lonestones of intraformational sediments, granitoids/ quartz and or metamorphic rocks constitute a discontinuous and minor contribution (generally $<10 \%$ ). Zones dominated by granule to pebble-sized intraformational clasts may correspond to the granulated facies of Domack et al. (1999), and interpreted to represent deposition during the "lift-off" phase of retreating grounded ice.

In Sequence 10, the glacial minima is recorded by a monogenic $(100 \%$ volcanic clasts and 31 clasts $/ \mathrm{m})$ interval whereas the overlying and underlying intervals in the same sequence show more heterogeneous compositions: sedimentary + volcanic $(48$ clasts $/ \mathrm{m})$ and volcanic + metamorphic $>$ sedimentary + intrusive ( 44 clasts $/ \mathrm{m}$ ) assemblages, respectively.

Consistently with the gravel-fraction compositions, the sand fractions from the open-water diatomites in Sequences 10, 13 and 15 are dominated by well-preserved volcanic lithics and glass. Moreover, sand-grain data indicate the diamictite at the base of Sequence 14 has a consistent provenance signal throughout, and this provenance signal continues through to the thin $(0.2 \mathrm{~m})$ sandstone unit that caps it. This sandstone contains abundant mudstone and diamictite intraclasts. Unlike the diamictite samples, clasts in this sandstone were not disaggregated, as their grain size was clearly a product of the depositional processes (e.g., cross-rippled, well sorted sandstone). However, to maintain consistency, these intraclasts were not included in the modal analysis, but visual estimate places their abundance at ca. $30-40 \%$. Despite this, the provenance of this sandstone is almost identical with that of the underlying stratified diamictite indicating that it associated directly to grounding line processes during glacial retreat, as similar glacimarine deposits have been documented in short sediment core document LGM retreat of the Antarctic ice sheet in the Ross Sea (e.g., "granulated facies" of Domack et al., 1999) and from beneath the Amery Ice Shelf (Hemer et al., 2007). This sandstone is overlain by a series of volcanic sands consisting almost entirely of angular and vesicular volcanic glass. The mudstone overlying the volcanic sandstone shows a similar provenance signal to the diamictite at the base of Sequence 14, as well as the diamictite in the overlying Sequence 13. This similarity in sand-grain provenance to the overlying diamictite suggests that the mudstones in the upper part of Sequence 14 were likely the product of grounding-line processes associated with glacial re-advance, rather than the fine-grained, distal component of volcanic sediment flows associated with the underlying volcanic sandstone.

Figure 5. Lithostratigraphy and sequence stratigraphy of the uppermost $200 \mathrm{~m}$ of AND-1B core. Plotted alongside (left to right): sand fractions compositions, clast compositions (relative proportions), clast abundance (average number of clasts per meter), ratio of volcanic clasts to the total number of clasts (per meter) and glacial proximity curve as determined by McKay et al. (2009). Age intervals are based on the initial age model of Wilson et al. (2007a). Lithostratigraphy after Krissek et al. (2007). 

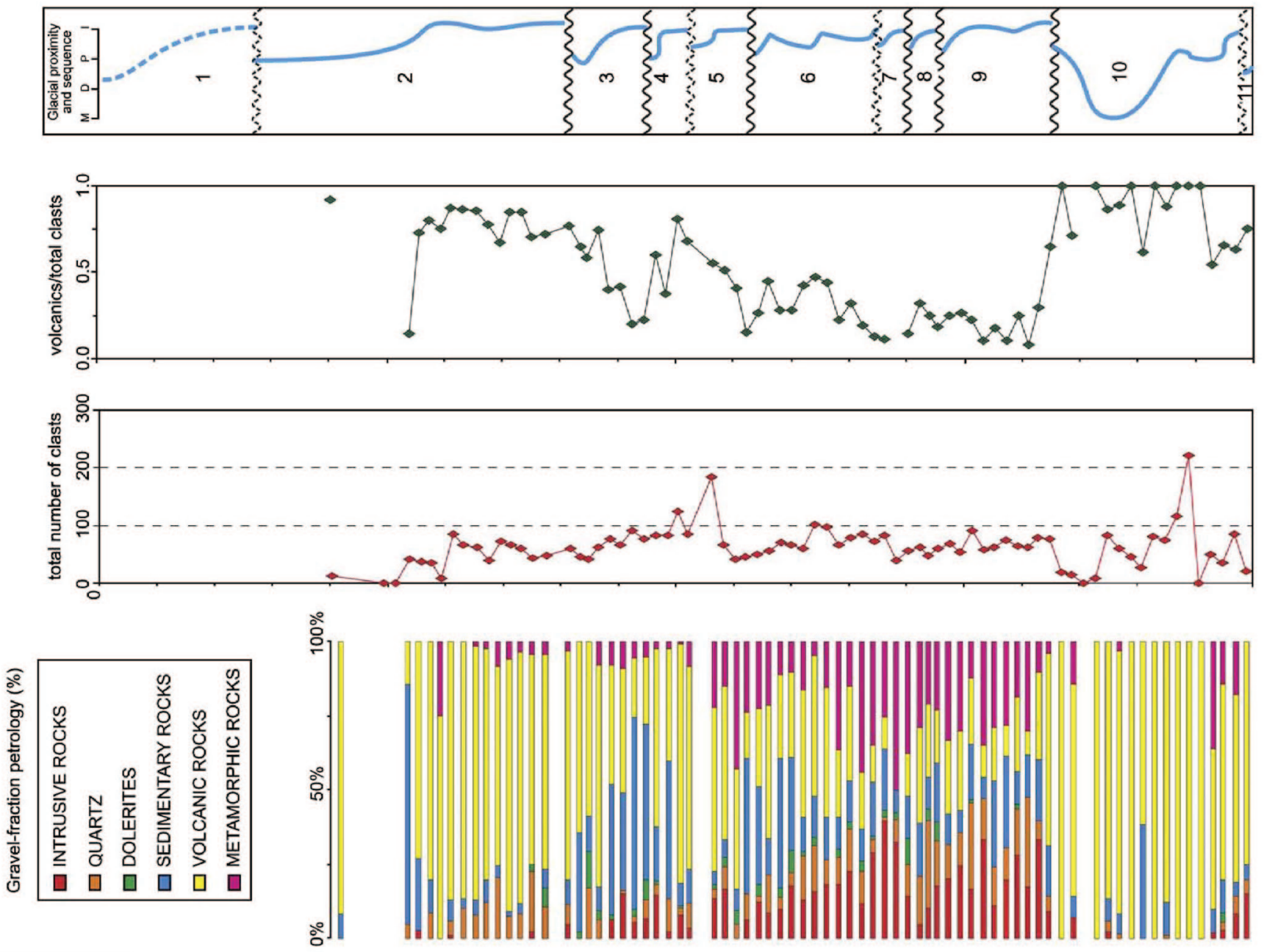

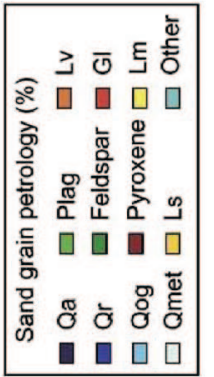

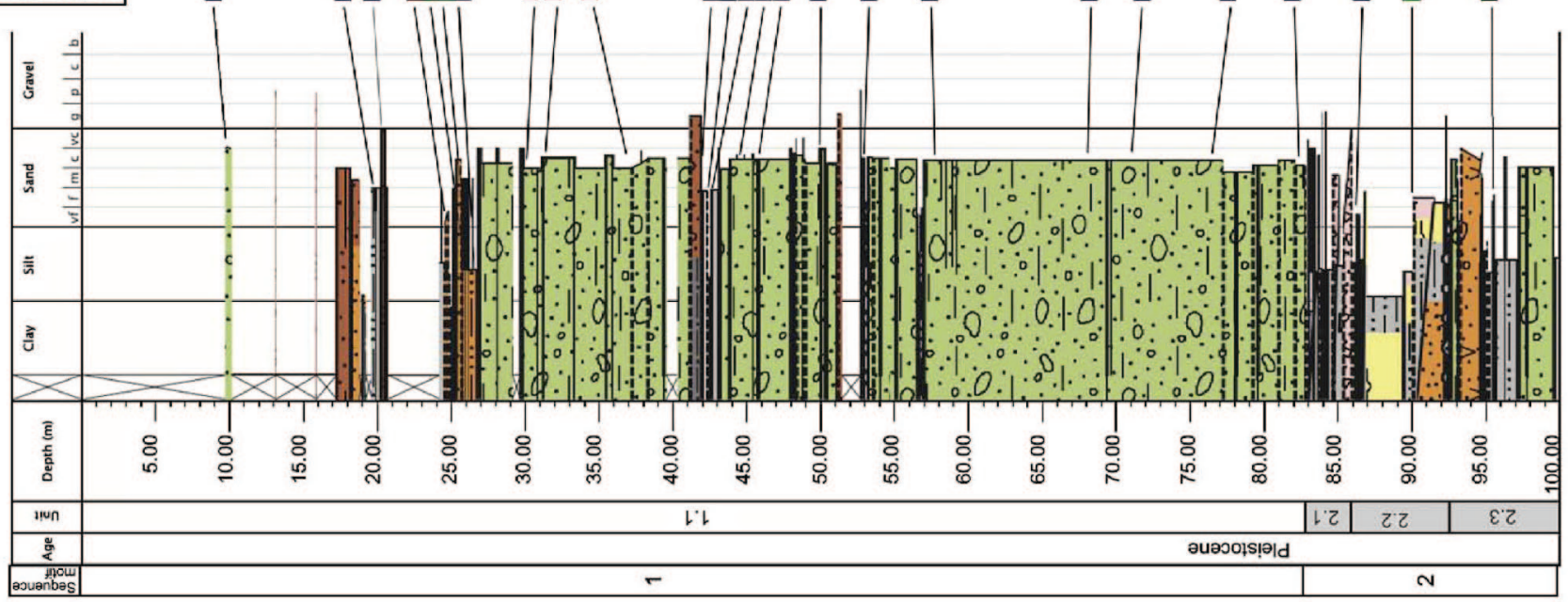



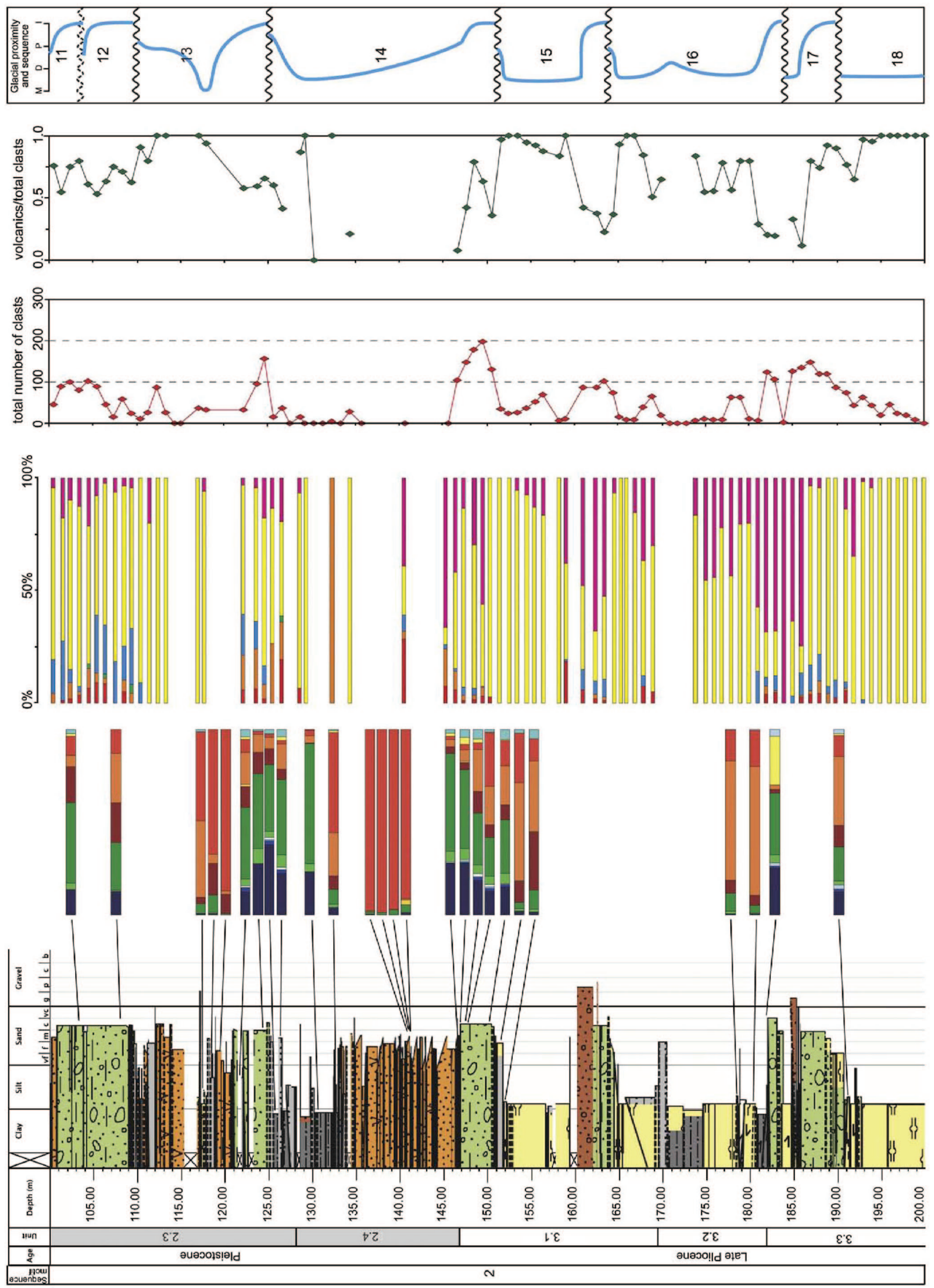


\section{Discussion}

Petrological data from AND-1B indicate that the supply of basement-sourced debris was mainly provided by distal areas located in the EAIS outlet glaciers south of Minna Bluff (Skelton-Mulock glacier region) and that provenance variations at AND-1B include both long-term and high-frequency patterns. Long-term compositional trends based on sand- and gravel-fraction petrology can be usefully discussed taking into account the large-scale features of the sedimentary record and the regional setting such as: (1) changes in glacimarine processes associated with changing ice sheet thermal regimes, as identified by the cycle "motifs" of McKay et al. (2009); (2) short-term compositional changes through individual glacial/interglacial cycles; (3) correlation (where chronology allows) with sedimentary records recovered by other drill cores in the McMurdo Sound region; and (4) the previous models of past ice sheet configurations in the Ross Sea (e.g., Denton and Hughes, 2002).

\subsection{Provenance shifts associated with changing ice sheet thermal regime}

The most significant observed long-term compositional shift in AND-1B occurs at ca. 82.7 mbsf, which coincides with a shift in the sequence "motifs" identified by McKay et al. (2009) and used to identify changes in past ice-sheet thermal regimes.

In comparison to Motif 2, Motif 1 cycles ( 82.7 to $0 \mathrm{mbsf}$ ) display variable but persistently high clast abundances $(>50 / \mathrm{m})$, more varied lithological assemblages including higher abundances of dolerite and an enrichment of Beacon sourced sand grains. Glacial/interglacial cycles in the uppermost Motif 1 sequences in AND-1B (e.g., ca. 52-25 mbsf) have higher volcanic component compared to the basement clast dominated Motif 1 sequence at the bottom of the Late Pleistocene interval (e.g., 82.7-52 mbsf) (Figures 2 \& 5). Although TAM-debris abundance decreases in the upper part of Motif 1 , the abundance of Beacon and Ferrar supergroup debris are still elevated in both the sand and gravel fraction, compared to Motif 2 cycles (Figure 2).

The coupling of these compositional differences with the sequence motifs indicates that the long-term shifts in provenance (e.g., the up-core increasing trend of TAM-sourced debris) occurred in concomitance with significant changes in ice-sheet volume, glacial thermal regime and climate.

This provenance shift in AND-1B probably reflects important differences in the dispersion processes of sediments and in the erosional patterns which were active during each regime. The sharp increase of basement clasts and clasts sourced by the Beacon and Ferrar supergroups at the transition at $82.7 \mathrm{mbsf}$ from Motif 2 sequences (below) to the polar-type style of Motif 1 sequences (above) point to a significant rearrangements of on-shore sediment dispersal system involving an increased contribution of glacial erosion, transport and deposition of glacial debris supplied from the Transantarctic Mountains. Since provenance inferences based on basement clast petrography suggest the SkeltonMulock glacier area as the unique source region throughout the investigated core section (including the lonestones in glacial minima facies, such as diatomite), the compositional changes at the Motif 2 to Motif 1 transitions could represent a change in the relative contribution of ice sourced from subtly different subglacial bedrocks within the Mulock or Skelton paleo-drainage systems, although constraining the extent of this change is difficult due to the poor outcrop extension and limited amount of geological data for TAM rock units south of the Skelton Glacier.

One theoretical explanation for these compositional changes is that the provenance signal could reflect a thicker EAIS, as this would result in ice entraining stratigraphically higher bedrock, in this case the Beacon Supergroup and Ferrar Dolerite sills, overlying the Granite Harbor Intrusive Complex in the Skelton-Mulock glacier region (McKay, 2008). The sharp increase of the TAM-sourced clasts in the Pleistocene section at CIROS-2 (San- droni and Talarico, 2006) could indicate a similar climatic signal. Reconstructed glacial flow lines during glacial maxima for the Pleistocene sediments at CIROS-2 (Ehrmann and Polozek, 1999; Sandroni and Talarico, 2006) indicate periods of expansion of grounded ice from the McMurdo Sound into the Ferrar Glacier paleo-valley, suggesting that if thickening of EAIS did occur in the mid Pleistocene, it was not expansive enough to override the TAM sector north of Minna Bluff. Moreover, as discussed in the following sections, changes in paleogeography might have strongly influenced sediment provenance and complicated the climatic signal. In concert with a higher dilution due to local derived volcanic debris, the decrease in Beacon sourced clasts and sand grains in the Pliocene section could also reflect the warmer style of glaciation for the Motif 2 sequences, when physical subglacial processes, enhanced by the poorly lithified nature of large parts of the Beacon Supergroup and increased subglacial porewater, resulted in a more pronounced disaggregation of the sediments into their constituents and a higher dispersal during glacial transport.

\subsection{Changing provenance through individual glacialy interglacial cycles}

The analysis of the petrological data in the uppermost $200 \mathrm{~m}$ at a higher resolution clearly reveals that a number of high-frequency cycles are superimposed on the previously discussed long-term compositional patterns (Figure 5). Previous petrological studies from sediment-gravity cores taken from beneath the McMurdo Ice Shelf in the AND-1B drill-site area indicated that glacially derived diamicts (deposited during retreat of Last Glacial Maximum ice) have a strong Transantarctic Mountain provenance signal, while Holocene muds and sands are dominated by McMurdo Volcanic Group sediments (Barrett et al., 2005; McKay et al., 2008). Despite some down-core variability, the short-term compositional changes are indicative of systematic and significant fluctuations in the relative contribution of different source rock units to the supply of sediments through the transitions from glacial maxima (glacial) to glacial minima (inter-glacial) periods. Generally, the composition of interglacial facies are dominated by local volcanic products (mainly primary deposits but also reworked felsic/intermediate lavas), but they include a variable content of lonestones of basement lithologies, such as the distinctive low-grade metasediments occurring as lonestones in diatomite facies, which point to a persistent involvement of the same provenance area identified for the diamictite units. In this context, the volcanic dominated assemblages would require that iceberg rafting at the AND-1B drill site was mostly influenced by calving either from (proto-) Ross Island glaciers, or from the Koettlitz Glacier near the base of Mt. Discovery and Mt. Morning (i.e., areas with extensive volcanic bedrocks). On the other hand, the association of the volcanic clasts with Skelton-Mulock glacier derived lonestones (e.g., in diatomite units, LSUs 3.5, 3.6) would imply that major calving processes should have been active also in the area between Mulock Glacier and northern side of Mt. Morning - where both volcanic and metamorphic bedrock is present - with possible pinning of ice tongues along Minna Bluff. Detailed analysis of the ice rafted debris (IRD) fraction in the AND-1B core require additional samples and new investigations are planned to integrate the petrological data with other dataset (including microfossil and bulk-rock geochemical compositions). Whatever the precise origin of IRD is, all the mentioned glaciers are expected to have expanded during open-water conditions, (assuming they had in the past the present-day low-altitude catchments) as open-water conditions in the McMurdo Sound region would have provided an increased precipitation source (e.g., Kellogg et al., 1979). Another important implication arises from the compositional and sedimentological features of Motif $1 \mathrm{cy}-$ cles in the Pleistocene section. Consistent with sedimentological evidence (McKay et al., 2009), the high proportion of subglacial and grounding-line proximal deposits, together with the occur- 
rence of granitoid and metamorphic rocks known from the Skelton Glacier region (Talarico et al., 2007) implies existence of a grounded ice sheet throughout most of the Late Pleistocene. Although additional ages are needed to increase the resolution of the model age, available age constraints (Wilson et al., 2007a) suggest that a grounded ice sheet should have persisted for much of this time when 80-120 ka fluctuations in large northern hemisphere ice sheets occurred (Imbrie et al., 1993), with associated eustatic changes (up to $120 \mathrm{~m}$ ) (Fairbanks, 1989) and super-warm interglacial periods, for which in Antarctica ice-core records indicated polar temperatures warmer than today (e.g., Petit et al., 1999; EPICA community members, 2004). Consequently, the apparently persistent influence of marine-based ice sheets in the Ross Embayment throughout most of the Late-Mid Pleistocene record would require appropriate changes in the volume of Northern Hemisphere ice in order to drive and account for observed eustatic changes.

\subsection{Correlation to previous drill cores from McMurdo Sound}

As in previous Late Neogene cores recovered in the McMurdo Sound region on the western edge of the Victoria Land Basin (e.g., MSSTS-1, CIROS-2, Cape Roberts Project; Hambrey et al., 1989; Talarico and Sandroni, 1998; Talarico et al., 2000; Sandroni and Talarico, 2006), the AND-1B borehole provides a clear evidence of a multi-component source for the supply of sand grains and granule- to cobble-sized clasts to the Late Neogene sedimentary sequences. A tectonic influence on clast compositional patterns was documented by Smellie $(2000,2001)$ and Sandroni and Talarico (2001) in the lower Miocene to Oligocene record of the Victoria Land Basin recovered at CRP-3 and CRP-2 drill sites. In contrast, the clasts and sand petrology data from the younger (Plio-Pleistocene) AND-1B record have not yet revealed a clear tectonic control, and are more readily interpreted in terms of variable ice volume (retreat/advance), with a unique flow reconstruction (detailed below) that can be considered valid for the entire record presented here.

The observed distribution of the volcanic component in the AND-1B uppermost $400 \mathrm{~m}$, with higher abundances restricted to the Pliocene section, is similar to the pattern recognized by Sandroni and Talarico (2006) in the CIROS-2 record, where volcanic clasts range from 30 up to $65 \%$ in the Lower Pliocene section: between 8 and 20\% in the Upper Pliocene; and are rare (but abundant in the sand fraction) in the Pleistocene section.

Despite lower abundances in CIROS-2, the proportion of the volcanic component follows the same up-core decreasing trend recognized in the AND-1B. The lower volcanic contribution to the CIROS-2 record probably reflects the different geographic location of this site, being closer to the flank shoulder of the TAM, and more distal from Cenozoic volcanism of the McMurdo Volcanic Group than the AND-1B site. The lower amounts of volcanic debris in the Pleistocene section of CIROS-2 could testify to a more effective mixing processes with more abundant basement clasts, which were sourced in the Blue Glacier-Miers Valley area, south of the site (Sandroni and Talarico, 2006).

Alternatively, the higher amounts of volcanic debris in the Pliocene section would reflect the progressive building of the Discovery sub-province area (namely, Brown Peninsula and Black Island exposures at ca. 2.7-2.1 Ma; Kyle, 1981), which offered increasingly larger volcanic areas in Late Pliocene, and may have created a barrier restricting the northwestern movement of grounded ice into McMurdo Sound after their construction.

\subsection{Integration with previous ice-sheet models for the Ross Embayment}

The identification of the Skelton-Mulock glacier area as the most likely source region for the basement clasts in AND-1B glacial sediments plays a key role in the reconstruction of ice flow during the phases of grounded ice in the McMurdo Sound region. In modern time, the sedimentary processes at the AND-1B drill site occur underneath the NW of the Ross Ice Shelf, that is largely fed by ice streams that drain the WAIS, but with its western margin nourished by EAIS outlet glaciers, including Byrd and Skelton glaciers, all with flow lines passing east of Ross Island (Figure 1C). A critical point in analyzing our provenance dataset for its value to provide new constraints to glaciological models for the Plio-Pleistocene time is to consider how changes in glacial volume over either West or East Antarctica may have altered the flow-line paths of Transantarctic Mountain outlet glaciers that feed into the Windless Bight Basin. Conceptually, a thicker WAIS may result in diverting more ice derived from the Byrd Glacier region, rather than the Mulock or Skelton glaciers, into the vicinity of AND-1B (compare Figure 6A with 6B).

Based on petrographical analysis of the sand fraction Licht et al. (2005) presented a provenance study of Late Quaternary tills in the Ross Sea comparing them to till samples from West Antarctica and the Transantarctic Mountains outlet glaciers (including Byrd and Darwin Glaciers). Because the core samples from the Ross Sea did not contain enough gravel to provide statistically meaningful results Licht et al. (2005) did not include provenance information from the gravel fraction of investigated samples.

Nevertheless, their study concluded that tills deposited in the central Ross Sea were deposited at the convergence of East and West Antarctic Ice Sheet derived ice (i.e., a similar scenario to Figure 6B), indicating that southern Transantarctic Mountain outlet glaciers are a likely source for sediments in AND-1B.

Consistent with Licht et al. (2005) results, the provenance constraints derived from the AND-1B core provide further evidence that even in Plio-Pleistocene time EAIS outlet glaciers (such as Skelton and Mulock glaciers) acted as the main ice source during glacial maxima in the region. As a further step in discussing possible ice dynamic scenarios and specifically the influence of the EAIS on the AND-1B record, we should take into account that glaciological reconstructions of grounded ice expansion within the Ross Embayment during the LGM (Denton and Hughes, 2000, 2002) suggest an approximately equal contribution of East and West Antarctic sourced ice feeding into grounded ice in the Ross Sea area. Previous petrographic studies from the Ross Sea suggest a relatively equal contribution from each source during the LGM (e.g., Licht et al., 2005).

From this point of view, when compared to present-day glacial setting (Figure 1C) and glaciological reconstructions of the LGM ice sheets in the Ross Sea (e.g., Denton and Hughes, 2002; Kellogg et al., 1996; Licht et al., 2005), the glaciological model based on the available provenance constraints requires a significant ice volume derived from both West and East Antarctica in order for flow lines of the southern TAM outlet glaciers to pass into the McMurdo region during glacial periods, and also to maintain an ice shelf during ensuing interglacial retreats, with an overall ice-flow pattern similar to the configurations already proposed by several authors for the Last Glacial Maximum (ca. $20 \mathrm{kyr}$ ) (Drewry, 1979; Kellogg et al., 1996; Denton and Hughes, 2002; Hulbe and MacAyeal, 1999; Fahnestock et al., 2000; Wilson, 2000).

Using these arguments, the sedimentary cycles documented in AND-1B have been interpreted as the record of the expansion and contraction of a marine-based ice sheet across the western Ross Embayment, derived from both East and West Antarctica (Naish et al., 2009; McKay et al., 2009). The TAM outlet glaciers alone do not provide enough volume to maintain a marine-based ice sheet or ice shelf in the Ross Embayment (Pollard and DeConto, 2009). This view of deposition by grounded ice in AND-1B as representing widespread ice sheet growth in the Ross Sea, with contributions from both East and West Antarctica is supported by the style of erosion within these strata - laterally extensive, sub-horizontal erosion surfaces, judging from calving line parallel seismic cross-sections (Naish et al., 2007).

Changes in paleogeography represent an additional complexity that should be considered in analyzing the available petrological data set. Indeed, the emergence of major volcanic centers during deposition of the drill core strata is likely to have altered the provenance signal and past glacial flow-line pathways. 

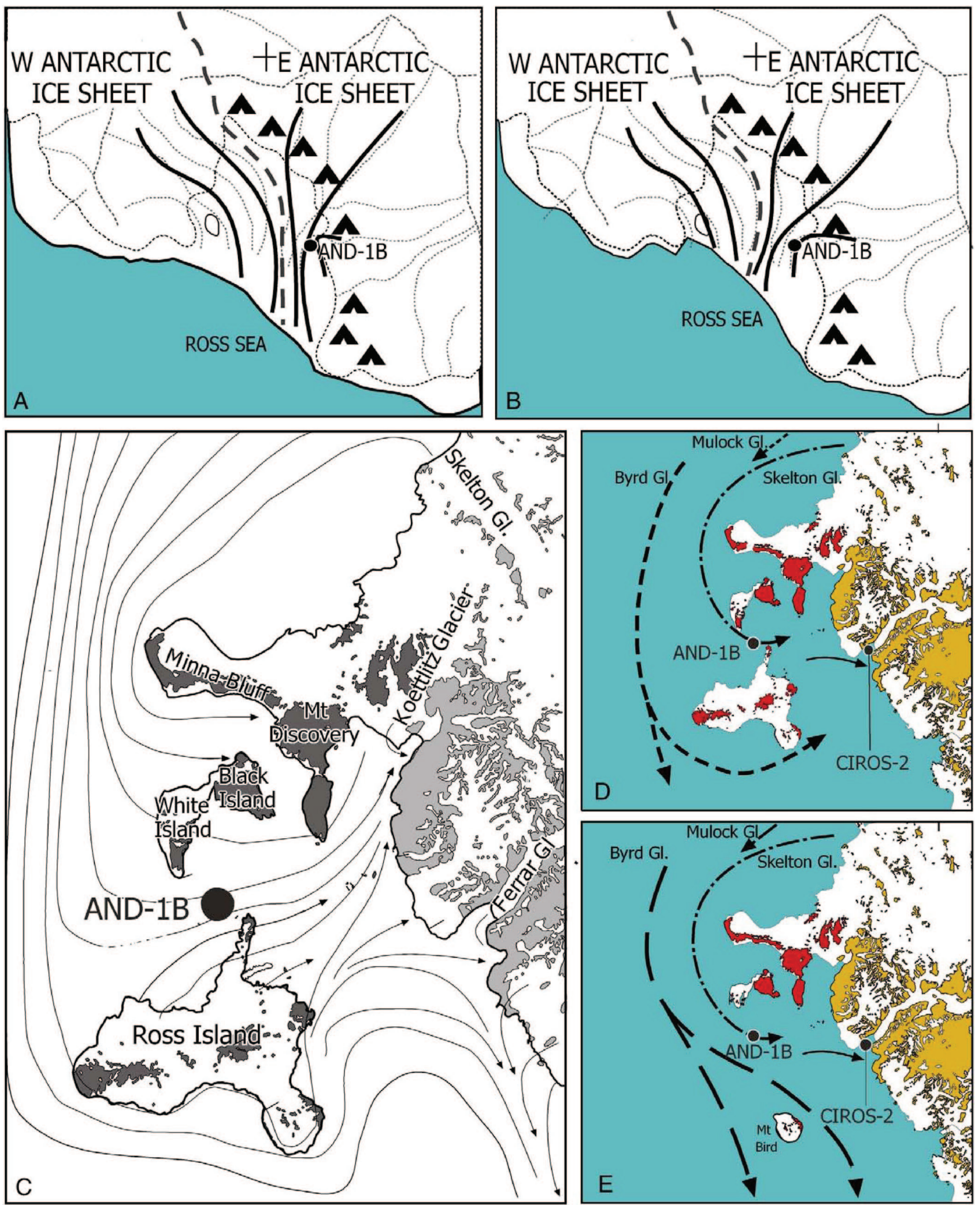

Figure 6. (A) and (B) Hypothesized effect on glacial flow lines for two different glacial maxima scenarios, where the relative contribution of East versus West Antarctic Ice Sheets to glacial advance in the Ross Embayment is changed. Under the scenario of a smaller and thinner WAIS (A), East Antarctic Ice Sheet flow lines may extend further into the central Ross Sea. (A) Dominant WAIS and (B) dominant EAIS. (C) LGM flow line reconstruction for the McMurdo Sound region based on geological and geomorphological evidence (Denton and Hughes, 2002). (D) and (E) Reconstructed pathways for ice sourced from the southern TAM outlet glaciers (Skelton Gl. and Mulock Gl.) into the AND-1B drill site during the period of glacial expansion in the Late Pleistocene (D) and in the Pliocene (E) (this study). Flow lines in the CIROS-2 area in (E) are after Sandroni and Talarico (2006), those in (D) are based on interpretations reported in Barrett and Hambrey (1992), Ehrmann and Polozek (1999), and Sandroni and Talarico (2006). Position of Byrd Glacier flow lines is only inferred by comparison with the LGM configuration. 
The ubiquitous coexistence in the AND-1B core of the variable (but often dominant) volcanic component with Skelton-Mulock derived debris requires a pre-depositional mixing process during the erosion or the transport phases. The variable incorporation of volcanic debris into basal debris layer of grounded ice sourced from outlet glaciers south of Minna Bluff may be explained as the result of localized modifications in the ice-sheet flow pattern resulting from changes in the paleogeographic setting. During the investigated time window (3.5 Ma to present), previously formed volcanic centers (e.g., Minna Bluff, White Island, Mt. Discovery) located between the MIS drill site and the Skelton area were progressively flanked to the north by the emergence of Mt. Terror at ca. 1.75 Ma (Wright and Kyle, 1990b), and Hut Point Peninsula and Mt. Erebus at ca. 1.3 Ma (Esser et al., 2004).

Volcanic activity as young as $0.17 \mathrm{Ma}$ (Cooper et al., 2007) at the northern margin of the White Island (oldest volcanism at 7.65 Ma) suggests that other presently not exposed areas or submarine volcanic centers (as indicated by magnetic anomalies; Wilson et al., 2007b) could have contributed volcanic clasts to the AND-1B drill site. From this point of view, the advance of a grounded ice sheet with a basal debris load of Skelton-Mulock glacier derived basement clasts would be expected to incorporate a significant, but variable, amount of proximal volcanic debris depending on the availability of volcanic bedrock in the drainage system at that time.

\section{Conclusions}

The present study demonstrates the significance of petrological investigations of the sand fraction and of granule- to cobblesized clasts in the AND-1B core for reconstructing source areas and transport directions for the Antarctic ice sheet in the McMurdo Sound area throughout the Plio-Pleistocene.

In the entire sedimentary record, diamictites interpreted as glacial maxima deposits contain a clast content that is consistent with grounded ice sourced from the Skelton-Mulock glacier catchments.

The reconstructed ice directions and ice dynamic model are comparable to the configurations proposed by Drewry (1979), Kellogg et al. (1996), and Denton and Hughes (2000, 2002) for the grounded ice expansion within the McMurdo Sound during the LGM, and they are also consistent with ice-flow patterns previously reconstructed for Pliocene (Sandroni and Talarico, 2006) and Pleistocene (Barrett and Hambrey, 1992; Ehrmann and Polozek, 1999; Sandroni and Talarico, 2006) glacial settings in the region. In agreement with these previous studies and sedimentological evidence, the provenance data indicate that a large, marine-based ice sheet has periodically occupied the Ross Embayment throughout the Plio-Pleistocene, and glacial advances at the AND-1B drill site were not the result of localized ice cap growth on bathymetric high in the Ross Sea, or advance of local glaciers in the McMurdo Sound region (e.g., Ferrar, Blue and Koettlitz glaciers).

A major change in diamictite provenance at $82.7 \mathrm{mbsf}$ in AND-1B coincides with a change in sedimentary cycle architecture that has previously been interpreted as representing the transition to the modern style of cold polar ice sheet (Naish et al., 2008; McKay et al., 2009). In the polar-style glacial/interglacial cycles (Mid-Late Pleistocene, above $82.7 \mathrm{mbsf}$ ), diamictites show high amounts of Skelton-Mulock sourced clasts, supplied from both basement and overlying Beacon and Ferrar supergroups, and they also include a variable contribution from reworking of glacial sediments that were deposited during earlier glacial activity. Consistent with sedimentological evidence (McKay et al., 2009) and available age constraints (Wilson et al., 2007a), the high proportion of subglacial and grounding-line proximal deposits sourced from distal EAIS glaciers implies persistence of a grounded ice sheet throughout most of the Late Pleistocene. Consequently a ramification of the ice model based on the AND$1 \mathrm{~B}$ record would require appropriate changes in the volume of
Northern Hemisphere ice in order to drive and account for observed eustatic changes in Mid-Late Pleistocene time.

In the underlying Motif 2 diatomite-diamictite cycles (Pliocene, below $82.7 \mathrm{mbsf}$ ) clast compositions in the diamictites indicate that the grounded ice was sourced in the same region (Mulock-Skelton) as for the Pleistocene record. However, the main debris load was picked up from volcanic centers in the McMurdo Sound area. Similarly, associated glacial minima sediments (i.e., diatomite intervals) are dominated by volcanic clasts indicating that IRD content during interglacial was dominated by calving of glaciers from Ross Island or the Koettlitz Glacier region. Nevertheless, metasediments consistent with calving from the Skelton and Mulock glacier area do constitute a subordinate component of some IRD intervals in AND-1B suggesting that the Ross Ice Shelf was much smaller in size during Pliocene interglacials than at present, as the calving line must have retreated past the mouths of these two TAM outlet glaciers, in order for them to have produced debris laden icebergs.

Changes in paleogeography related to the emergence of several volcanic centers during the deposition of the drill core are identified as an important additional factor that could have altered the provenance signal. The marked dilution of basement clasts sourced from EAIS glaciers south of Minna Bluff with abundant volcanic debris could be explained with the incorporation of the volcanic debris in the ice coming from the SkeltonMulock glacier region on its way to the AND-1B drill-site area. In this context, dating of volcanic pebbles in the AND-1B core and improved chronology of the volcanic evolution in the McMurdo region should help to resolve some of the uncertainties. In the meantime, numerical models need to be developed to test the hypotheses presented here for past glacial flow lines, taking into account both changes in paleogeography and the relative ice fluxes from East and West Antarctica.

Acknowledgments - We would like to acknowledge G. S. Wilson and two anonymous referees for Global and Planetary Change for their helpful comments and suggestions, and the whole ANDRILL MIS Science Team for their contribution to the successful drilling project. The research was carried out with the financial support of the Italian Programma Nazionale di Ricerche in Antaride. The ANDRILL project is a multinational collaboration between the Antarctic programs of Germany, Italy, New Zealand, and the United States. Antarctica New Zealand is the project operator and developed the drilling system in collaboration with Alex Pyne at Victoria University of Wellington and Webster Drilling and Enterprises Ltd. Antarctica New Zealand supported the drilling team at Scott Base; Raytheon Polar Services Corporation supported the science team at McMurdo Station and the Crary Science and Engineering Laboratory. The ANDRILL Science Management Office at the University of Nebraska-Lincoln provided science planning and operational support. Scientific studies are jointly supported by the US National Science Foundation, NZ Foundation for Research, Science and Technology, and the Royal Society of NZ Marsden Fund, the Italian Antarctic Research Program, the German Research Foundation (DFG) and the Alfred Wegener Institute Polar and Marine Research.

\section{References}

Allibone, 1992 • A. H. Allibone, Low pressure/high temperature metamorphism of Koettlitz Group schists in the Taylor Valley and Ferrar Glacier regions, New Zealand Journal of Geology and Geophysics 35 (1992), pp. 115-127.

Allibone et al., 1993a - A. H. Allibone, S. C. Cox, and R. W. Smillie, Granitoids of the Dry Valleys area, southern Victoria Land: Geochemistry and evolution along the early Paleozoic Antarctic craton margin, New Zealand Journal of Geology and Geophysics 36 (1993), pp. 281-297.

Allibone et al., 1993b - A. H. Allibone, S. C. Cox, I. J. Graham, R. W. Smillie, R. D. Johnstone, S. G. Ellery, and K. Palmer, Granitoids of the Dry Valleys area, southern Victoria Land, Antarctica: Plutons, field relationships, and isotopic dating, New Zealand Journal of Geology and Geophysics 36 (1993), pp. 281-297.

Barrett, 1999 - P. Barrett, Antarctic climate history over the last 100 million years, Terra Antartica Reports 3 (1999), pp. 53-72. 
Barrett and Hambrey, 1992 - P. J. Barrett and M. J. Hambrey, Plio-Pleistocene sedimentation in the Ferrar Fiord, Antarctica, Sedimentology 39 (1992), pp. 109-123.

Barrett et al., 2005 - P. J. Barrett, L. Carter, G. B. Dunbar, E. Dunker, G. Giorgetti, M. A. Harper, R. M. McKay, F. Niessen, U. Nixdorf, A. R. Pyne, C. Riesselmann, N. Robinson, C. Hollis, and P. Strong, Oceanography and sedimentation beneath the McMurdo Ice Shelf in Windless Bight, Antarctica, Antarctic Data Series 25 (2005), pp. 1-90.

Borg et al., 1989 - S. G. Borg, D. J. DePaolo, E. D. Wendlandt, and T. G. Drake, Studies of granites and metamorphic rocks, Byrd Glacier area, Antarctic Journal of the United States 24 (1989), pp. 19-21.

Cape Roberts Science Team, 1998a - Cape Roberts Science Team, Quaternary strata in CRP-1, Cape Roberts Project, Antarctica, Terra Antartica 5 (1998), pp. 31-62.

Cape Roberts Science Team, 1998b - Cape Roberts Science Team, Miocene strata in CRP-1, Cape Roberts Project, Antarctica, Terra Antartica 5 (1998), pp. 63-124.

Cape Roberts Science Team, 1999 - Cape Roberts Science Team, Studies from the Cape Roberts Project, Initial Report on CRP-2/2A, Ross Sea, Antarctica, Terra Antartica 6 (1999), pp. 1-168.

Carosi et al., 2007 • R. Carosi, F. Giacomini, F. Talarico, and E. Stump, Geology of the Byrd Glacier Discontinuity (Ross Orogen): New survey data from the Britannia Range, Antarctica. In: A. K. Cooper, C. R. Raymond, et al., Editors, Antarctica: A Keystone in a Changing World - Online Proceedings of the 10th ISAES, USGS Open-File Report 2007-1047, Short Research Paper 030 (2007), 6 pp.; doi:10.3133/of2007-1047.srp030

Cook, 1997 - Y. Cook, The Skelton Group and the Ross Orogeny. Ph. D. Thesis, University of Otago, Dunedin, 1997.

Cook, 2007 - Y. A. Cook, Precambrian rift-related magmatism and sedimentation, south Victoria Land, Antarctica, Antarctic Science 19 (2007), pp. $471-484$

Cook and Craw, 2001 - Y. A. Cook and D. Craw, Amalgamation of disparate crustal fragments in the Walcott Bay - Foster Glacier area, South Victoria Land, Antarctica, New Zealand Journal of Geology and Geophysics 44 (2001), pp. 403-416.

Cook and Craw, 2002 • Y. A. Cook and D. Craw, Neoproterozoic structural slices in the Ross orogen, Skelton Glacier area, south Victoria Land, New Zealand Journal of Geology and Geophysics 45 (2002), pp. 133-143.

Cooper et al., 1987 - A. K. Cooper, F. J. Davey, and J. C. Behrendt, Seismic stratigraphy and structure of the Victoria Land Basin, Western Ross Sea, Antarctica. In: A. K. Cooper and F. J. Davey, Editors, The Antarctic Continental Margin: Geology and Geophysics of the Western Ross Sea vol. 5B (1987), pp. 27-76 Published by the Circum-Pacific Council of Energy and Mineral Resources, Houston.

Cooper et al., 1997 • A. F. Cooper, B. A. Worley, R. A. Armstrong, and R. C. Price, Synorogenic alkaline and carbonatitic magmatism in the Transantarctic Mountains of South Victoria Land, Antarctica. In: C. A. Ricci, Editor, The Antarctic region: geological evolution and processes, Terra Antartica Publication, Siena (1997), pp. 245-252.

Cooper et al., 2007 • A. F. Cooper, L. J. Adam, R. F. Coulter, G. N. Eby, and W. C. McIntosh, Geology, geochronology and geochemistry of a basinite volcano, White Island, Ross Sea, Antarctica, Journal of Volcanology and Geothermal Research 165 (2007), pp. 189-216.

Cottle and Cooper, 2006a - J. M. Cottle and A. F. Cooper, Geology, geochemistry and geochronology of an A-type granite in the Mulock Glacier area, southern Victoria Land, Antarctica, New Zealand Journal of Geology and Geophysics 49 (2006), pp. 191-202.

Cottle and Cooper, 2006b - J. M. Cottle and A. F. Cooper, The Fontaine Pluton: An early Ross Orogeny calc-alkaline gabbro from southern Victoria Land, Antarctica, New Zealand Journal of Geology and Geophysics 49 (2006), pp. 177-189.

Craddock, 1970 - C. Craddock, 1970. Tectonic map of Gondwana, in Geologic maps of Antarctica. Edited by Bushnell, V. C., and Craddock, C., Antarctic Map Folio Series, Folio 12, plate XXIII, Amer. Geogr. Soc., New York.

Denton and Hughes, 2000 • G. H. Denton and T. J. Hughes, Reconstruction of the Ross ice drainage system, Antarctica, at the Last Glacial Maximum, Geografiska Annaler 82A (2000), pp. 143-166.

Denton and Hughes, 2002 • G. H. Denton and T. J. Hughes, Reconstructing the Antarctic ice sheet at the Last Glacial Maximum, Quaternary Science Reviews 21 (2002), pp. 203-231.

Denton and Marchant, 2000 • G. H. Denton and D. R. Marchant, The geologic basis for a reconstruction of a grounded ice sheet in McMurdo Sound, Antarctica, at the Last Glacial Maximum, Geografiska Annaler 82A (2000), pp. 167-211.

Domack et al., 1999 • E. W. Domack, E. A. Jacobson, S. Shipp, and J. B. Anderson, Late Pleistocene-Holocene retreat of the West Antarctic icesheet system in the Ross Sea: Part 2. Sedimentologic and stratigraphic signature, GSA Bulletin 111 (1999), pp. 1517-1536.

Drewry, 1979 - D. J. Drewry, Late Wisconsin reconstruction for the Ross Sea region, Antarctica, Journal of Glaciology 24 (1979), pp. 231-244.

Drewry, 1983 - D. J. Drewry, Antarctica: Glaciological and geophysical folio, University of Cambridge, Scott Polar Research Institute, Cambridge,
United Kingdom (1983) 9 pp.

Ehrmann and Polozek, 1999 • W. Ehrmann and K. Polozek, The heavy mineral record in the Pliocene to Quaternary sediments of the CIROS-2 drill core, McMurdo sound, Antarctica, Sedimentary Geoleogy 128 (1999), pp. 223-244.

EPICA community members, 2004 - EPICA community members, Eight glacial cycles from an Antarctic ice core, Nature 429 (2004), pp. 623-628.

Esser et al., 2004 • R. P. Esser, P. R. Kyle, and W. C. McIntosh, 40Ar/39Ar dating of the eruptive history of Mount Erebus, Antarctica: Volcano evolution, Bulletin of Volcanology 66 (2004), pp. 671-686.

Fahnestock et al., 2000 • M. A. Fahnestock, T. A. Scambos, R. A. Bindschadler, and G. Kvaran, A millennium of variable ice flow recorded by the Ross Ice Shelf, Antarctica, Journal of Glaciology 46 (2000), pp. 652-664.

Fairbanks, 1989 • R. G. Fairbanks, A 17, 000 year glacio-eustatic sea level record: Influence of glacial melting rates on the Younger Dryas event and deep-ocean circulation, Nature 342 (1989), pp. 367-642.

Findlay et al., 1984 • R. H. Findlay, D. N. B. Skinner, and D. Craw, Lithostratigraphy and structure of the Koettlitz Group, McMurdo Sound, Antarctica, New Zealand Journal of Geology and Geophysics 27 (1984), pp. 513-536

Grindley and Warren, 1964 • G. W. Grindley and G. Warren, Stratigraphic nomenclature and correlation in the western part of the Ross Sea. In: R. J. Adie, Editor, Antarctic geology, North Holland Publishing Co., Amsterdam (1964), pp. 314-333.

Gunn and Warren, 1962 - B. M. Gunn and G. Warren, Geology of Victoria Land between the Mawson and Mulock glaciers, Antarctica, New Zealand Geological Survey (1962) 71.

Hambrey et al., 1989 - M. J. Hambrey, P. J. Barrett, and P. H. Robinson, Stratigraphy. In: P. J. Barrett, Editor, Antarctic Cenozoic history from the CIROS-1 drillhole, McMurdo Sound. DSIR Bulletin 245 (1989), pp. 23-48.

Harrington, $1965 \bullet$ H. J. Harrington, Geology and morphology of Antarctica. Biogeography and ecology in Antarctica, Monographiae Biologicae 15 (1965), pp. 1-71

Hemer et al., 2007 • M. Hemer, A. L. Post, P. E. O’Brien, M. Craven, E. M. Truswell, D. Roberts, and P. T. Harris, Sedimentological signatures of the sub-Amery Ice Shelf circulation, Antarctic Science 19 (2007), pp. 497-506.

Henrys et al., 2007 • S. A. Henrys, T. J. Wilson, J. Whittaker, C. R. Fielding, J. Hall, and T. R. Naish, Tectonic history of Mid-Miocene to Present southern Victoria Land basin, inferred from seismic stratigraphy, in McMurdo Sound, Antarctica. In: A. K. Cooper, C. R. Raymond, et al., Editors, Antarctica: A Keystone in a Changing World-Online Proceedings for the Tenth International Symposium on Antarctic Earth Sciences, USGS Open-File Report 2007-1047, Short Research Paper 049, 2007.

Horgan et al., 2005 • H. Horgan, T. Naish, S. Bannister, N. Balfour, and G. S. Wilson, Seismic stratigraphy of the Plio-Pleistocene Ross Island flexural moat-fill: A prognosis for ANDRILL Programm drilling beneath McMurdo-Ross Ice Shelf, Global and Planetary Change 45 (2005), pp. 83-97.

Hughes, 1977 • T. Hughes, West Antarctic ice streams, Reviews of Geophysics and Space Physics 15 (1977), pp. 1-46.

Hulbe and MacAyeal, 1999 - C. Hulbe and D. MacAyeal, A new numerical model of coupled inland ice sheet, ice stream, and ice shelf flow and its application to the West Antarctic Ice Sheet, Journal of Geophysical Research 104 (1999), pp. 349-366

Huybrechts, 2002 - P. Huybrechts, Sea-level changes at the LGM from icedynamic reconstructions of the Greenland and Antarctic ice sheets during the glacial cycles, Quaternary Science Reviews 21 (2002), pp. 203-231.

Imbrie et al., 1993 - J. Imbrie, A. Berger, E. A. Boyle, S. C. Clemens, A Duffy, W. R. Howard, G. Kukla, J. Kutzback, D. G. Martinson, A. McIntyre, A. C. Mix, B. Molfino, J. J. Morley, L. C. Peterson, N. G. Pisias, W. L. Prell, M. E. Raymo, N. J. Shackleton, and J. R. Toggweiler, On the structure and origin of major glaciation cycles. 2. The 100,000-year cycle, Paleo-oceanography 8 (1993), pp. 699-735.

Kellogg et al., 1979 • T. B. Kellogg, R. S. Truesdale, and L. E. Osterman, Late Quaternary extent of the West Antarctic ice sheet: New evidence from Ross cores, Geology 7 (1979), pp. 249-253.

Kellogg et al., 1996 • T. B. Kellogg, T. Hughes, and D. E. Kellogg, Late Pleistocene interactions of East and West Antarctic ice-flow regimes: Evidence from the McMurdo Ice Shelf, Journal of Glaciology 42 (1996), pp. 486-500.

Korsch, 1974 • R. J. Korsch, Petrographic comparison of the Taylor and Victoria Groups (Devonian to Triassic) in South Victoria Land, Antarctica, New Zealand Journal of Geology and Geophysics 17 (1974), pp. 523-541.

Kretz, 1983 - R. Kretz, Symbols for rock forming minerals, American Mineralogist 68 (1983), pp. 277-279.

Krissek et al., 2007 • L. A. Krissek, G. H. Browne, L. Carter, E. A. Cowan, G. B. Dunbar, R. M. McKay, T. Naish, R. Powell, J. Reed, T. I. Wilch, and the Andrill MIS Science Team, Sedimentology and stratigraphy of the AND-1B core, ANDRILL McMurdo Ice Shelf Project, Antarctica, Terra Antartica 14 (2007), pp. 185-222.

Kyle, 1981 - P. R. Kyle, Mineralogy and geochemistry of a basanite to phonolite sequence at Hut Point Peninsula, Antarctica, based on core from 
Dry Valley Drilling Project Drillholes 1, 2 and 3, Journal of Petrology 22 (1981), pp. 451-500.

Kyle, 1990 • P. R. Kyle, A. McMurdo volcanic group, western Ross Embayment. Introduction. In: W. E. Le Masurier and J. W. Thomson, Editors, Volcanoes of the Antarctic Plate and Southern Oceans, AGU Antarctic Research Series 48 (1990), pp. 19-25.

Kyle et al., 1981 • P. R. Kyle, D. H. Elliot, and J. F. Sutter, Jurassic Ferrar Supergroup tholeiites from the Transantarctic Mountains, Antarctica, and their relationship to the initial fragmentation of Gondwana. In: M. M. Cresswell and P. Vella, Editors, Gondwana Five, Fifth International Gondwana Symposium (1981), pp. 283-287.

Licht et al., 2005 - K. J. Licht, J. R. Lederer, and J. R. Swope, Provenance of LGM glacial till (sand fraction) across Ross embayment, Antarctica, Quaternary Science Reviews 24 (2005), pp. 1499-1520.

MacAyeal et al., 1996 • D. R. MacAyeal, V. Rommelaere, P. Huybrechts, C. L. Hulbe, J. Determann, and C. Ritz, An ice shelf model test based on the Ross Ice Shelf, Antarctica, Annals of Glaciology 23 (1996), pp. 46-51.

Mckay, 2008 • R. Mckay, Late Cenozoic (13-0 Myr) glacimarine sedimentology, facies analysis, and sequence stratigraphy from the Western Ross Embayment, Antarctica: Implications for the variability of the West Antarctic Ice Sheet. PHD thesis, Wellington University (unpublished), 2008.

McKay et al., 2008 • R. McKay, G. Dunbar, T. R. Naish, P. Barrett, L. Carter, and M. Harper, Retreat of the Ross Ice Shelf since the Last Glacial Maximum derived from sediment cores in deep basins surrounding Ross Island, Paleoclimatology, Paleogeography, Paleoecology 260 (2008), pp. 245-261.

McKay et al., 2009 - R. McKay, G. Browne, L. Carter, E. Cowan, L. Krissek, T. Naish, R. Powell, J. Reed, F. Talarico, and T. Wilch, The stratigraphic signature of the Late Cenozoic Antarctic ice sheets in the Ross Embayment, Bulletin of the Geological Society of America 121 (2009), pp. 1537-1561.

Mosola and Anderson, 2006 • A. B. Mosola and J. B. Anderson, Expansion and rapid retreat of the West Antarctic Ice Sheet in Eastern Ross Sea: Possible consequence of over extended ice streams?, Quaternary Science Reviews 25 (2006), pp. 2177-2196.

Naish et al., 2007 - T. R. Naish, R. D. Powell, R. H. Levy, and the ANDRILL MIS Science Team, Initial science results from AND-1B, ANDRILL McMurdo Ice Shelf Project, Antarctica,Terra Antartica 14 (2007), pp. 111-328.

Naish et al., 2008 - T. R. Naish, R. D. Powell, P. J. Barrett, R. H. Levy, S. Henrys, G. S. Wilson, L. A. Krissek, F. Niessen, M. Pompilio, R. Scherer, F. Talarico, and A. Pyne, Late Neogene climate history of the Ross Embayment from the AND-1B drill core: Culmination of three decades of Antarctic margin drilling, Antarctica: A keystone in a changing World. In: A. Cooper, et al., Editors, Proceedings of the 10th International Symposium on Antarctic Earth Sciences, The National Academies Press, Santa Barbara, Washington DC (2008), pp. 71-82.

Naish et al., 2009 • T. Naish, R. Powell, R. Levy, G. Wilson, R. Scherer, F. Talarico, L. Krissek, F. Niessen, M. Pompilio, T. Wilson, L. Carter, R. DeConto, P. Huybers, R. McKay, D. Pollard, J. Ross, D. Winter, P. Barrett, G. Browne, R. Cody, E. Cowan, J. Crampton, G. Dunbar, N. Dunbar, F. Florindo, C. Gebhardt, I. Graham, M. Hannah, D. Hansaraj, D. Harwood, D. Helling, S. Henrys, L. Hinnov, G. Kuhn, P. Kyle, A. Läufer, P. Maffioli, D. Magens, K. Mandernack, W. McIntosh, C. Millan, R. Morin, C. Ohneiser, T. Paulsen, D. Persico, I. Raine, J. Reed, C. Riesselman, L. Sagnotti, D. Schmitt, C. Sjunneskog, P. Strong, M. Taviani, S. Vogel, T. Wilch, and T. Williams, Obliquity-paced Pliocene West Antarctic ice sheet oscillations, Nature 458 (2009), pp. 322-328.

Petit et al., 1999 • J. R. Petit, J. Jouzel, D. Raynaud, N. I. Barkov, J. M. Barnola, I. Basile, M. Benders, J. Chappellaz, M. Davis, G. Delaygue, M. Delmotte, V. M. Kotlyakov, M. Legrand, V. Y. Lipenkov, C. Lorius, L. Pépin, C. Titz, E. Saltzman, and M. Stievenard, Climate and atmospheric history of the past 420,000 years from the Vostok ice core, Antarctica, Nature 399 (1999), pp. 429-436.

Pollard and DeConto, 2009 • M. Pollard and D. DeConto, Modelling West Antarctic Ice sheet growth and collapse through the last 5 million years, Nature 458 (2009), pp. 329-332.

Pompilio et al., 2007 • M. Pompilio, N. Dunbar, A. C. Gebhardt, D. Helling, G. Kuhn, P. Kyle, R. McKay, F. Talarico, S. Tulaczyk, S. Vogel, T. Wilch, and the ANDRILL-MIS Science Team, Petrology and geochemistry of the AND-1B Core, ANDRILL McMurdo Ice Shelf Project, Antarctica, Terra Antartica 14 (2007), pp. 255-288.

Ritz et al., 2001 - C. Ritz, V. Rommelaere, and C. Dumas, Modeling the evolution of Antarctic ice sheet over the last 420,000 years: Implications for altitude changes in the Vostok region, Journal of Geophysical Research-Atmospheres 106 (2001), pp. 31943-31964.

Rowell et al., 1993 - A. J. Rowell, M. N. Rees, E. M. Duebendorfer, E. T. Wallin, S. W. R. Van, and E. I. Smith, An active Neoproterozoic margin; evidence from the Skelton Glacier area, Transantarctic Mountains, Journal of the Geological Society of London 150 (1993), pp. 677-682.

Sandroni and Talarico, 2001 - S. Sandroni and F. M. Talarico, Petrogra- phy and provenance of basement clasts and clast variability in CRP-3 drillcore (Victoria Land Basin, Antarctica), Terra Antartica 8 (2001), pp. 449-467.

Sandroni and Talarico, 2004 • S. Sandroni and F. M. Talarico, Petrography and provenance of basement clasts in CIROS-1 core, McMurdo Sound, Antarctica, Terra Antartica 11 (2004), pp. 93-114.

Sandroni and Talarico, 2006 - S. Sandroni and F. M. Talarico, Analysis of clast lithologies from CIROS-2 core, New Harbor, Antarctica - implications for ice flow directions during Plio-Pleistocene, Palaeoleography, Palaeoclimatology, Palaeoecology 231 (2006), pp. 215-232.

Skinner, 1982 - D. N. B. Skinner, Stratigraphy and structure of low-grade meta-sedimentary rocks of the Skelton Group, southern Victoria Land - Does Teal Greywacke really exist? In: C. Craddock, Editor, Antarctic geoscience, University of Wisconsin Press, Madison (1982), pp. 555-563.

Smellie, 1998 - J. L. Smellie, Sand grain detrital modes in CRP-1: Provenance variations and influence of Miocene eruptions on the marine record in the McMurdo Sound region, Terra Antartica 5 (1998), pp. $579-587$.

Smellie, 2000 - J. L. Smellie, Erosional history of the Transantarctic Mountains deduced from sand grain detrital modes in CRP-2/2A, Victoria Land Basin, Antarctica, Terra Antartica 7 (2000), pp. 545-552.

Smellie, 2001 - J. L. Smellie, History of Oligocene erosion, uplift and unroofing of the Transantarctic Mountains deduced from sandstone detrital modes in CRP-3 drillcore, Victoria Land Basin, Antarctica, Terra Antartica 8 (2001), pp. 481-489.

Stern et al., 1991 - T. A. Stern, F. J. Davey, and G. Delisle, Lithostratic flexure induced by the load of the Ross Archipelago, southern Victoria land, Antarctica. In: M. R. A. Thomson, A. Crame, and J. W. Thomson, Editors, Geological Evolution of Antarctica, Cambridge University Press, Cambridge (1991), pp. 323-328.

Talarico and Sandroni, 1998 - F. Talarico and S. Sandroni, Petrography, mineral chemistry and provenance of basement clasts in the CRP-1 drillcore (Victoria Land Basin, Antarctica), Terra Antartica 5 (1998), pp. 601-610.

Talarico et al., 2000 - F. M. Talarico, S. Sandroni, C. Fielding and C. Atkins, Variability, petrography and provenance of basement clasts from CRP-2/2A drillcore (Victoria Land Basin, Antarctica), Terra Antartica 7 (2000), pp. 529-544.

Talarico et al., 2005 • F. M. Talarico, R. Findlay, and N. Rastelli, Metamorphic evolution of the Koettlitz Group in the Koettlitz-Ferrar Glaciers region (southern Victoria Land, Antarctica), Terra Antartica 12 (2005), pp. $3-23$.

Talarico et al., 2007 • F. M. Talarico, S. Sandroni, and MIS Science Team, Clast provenance and variability in MIS (AND-1B) core and their implications for the paleoclimatic evolution recorded in the Windless Bight - Southern McMurdo Sound area (Antarctica). In: A. K. Cooper et al., Editors, Program book for the 10th ISAES, IUGS Open-File Report 2007, 104, p. 14 (2007)

Tingey, 1991 - R. J. Tingey, The geology of Antarctica. Oxford Monographs on Geology and Geophysics 17, Clarendon Press, Oxford (1991).

Turnbull et al., 1994 - I. M. Turnbull, A. H. Allibone, P. J. Forsyth, and D. W. Heron, Geology of the Bull Pass - St Johns Range area, southern Victoria Land, Antarctica. Scale 1:50000. Institute of Geological \& Nuclear Sciences, Geological Map 14, 1 sheet +52 pp. Institute of Geological \& Nuclear Sciences Ltd, Lower Hutt, New Zealand, 1994.

Williams et al., 1971 • P. F. Williams, B. E. Hobbs, R. H. Vernon, and D. E. Anderson, The structural and metamorphic geology of basement rocks in the McMurdo Sound area, Antarctica, Journal of the Geological Society of Australia 18 (1971), pp. 127-142.

Wilson, 2000 - G. S. Wilson, Glacial geology and origin of fossiliferous-erratic-bearing moraines, southern McMurdo Sound, Antarctica - an alternative ice sheet hypothesis, Antarctic Research Series 76 (2000), pp. 19-37.

Wilson et al., 2007a - G. S. Wilson, R. Levy, G. Browne, N. Dunbar, F. Florindo, S. Henrys, I. Graham, W. McIntosh, R. McKay, T. Naish, Ohneiser, R. Powell, J. Ross, L. Sagnotti, R. Scherer, C. Sjunneskog, C. Strong, M. Taviani, D. Winter, and the ANDRILL MIS Science Team, Preliminary chronostratigraphy of the AND-1B core, ANDRILL McMurdo Ice Shelf Project, Antarctic, Terra Antartica 14 (2007), pp. 297-316.

Wilson et al., 2007b • G. S. Wilson, D. Damaske, H.-D. Möller, K. Tinto, and T. Jordan, The geological evolution of southern McMurdo Sound New evidence from a high-resolution aeromagnetic survey, Geophysical Journal International 170 (2007), pp. 93-100.

Wright and Kyle, 1990a - A. C. Wright and P. R. Kyle, Mount Bird. In: W. E. LeMasurier and J. W. Thomson, Editors, Volcanoes of the Antarctica Plate and Southern Oceans, American Geophysical Union, Antarctic Research Series 48 (1990), pp. 97-98.

Wright and Kyle, 1990b - A. C. Wright and P. R. Kyle, Mount Terror. In: W. E. LeMasurier and J. W. Thomson, Editors, Volcanoes of the Antarctica Plate and Southern Oceans, American Geophysical Union, Antarctic Research Series 48 (1990), pp. 99-102. 
MIS CORE - MODAL VARIATIONS IN CLAST LITHOLOGIES

0-200 MBSF

\begin{tabular}{|c|c|c|c|c|c|c|c|c|c|c|c|}
\hline \multirow[b]{2}{*}{ box } & \multicolumn{2}{|l|}{ Depht } & \multicolumn{8}{|c|}{ NUMBER of CLASTS PER LITOLOGY } & \multirow[b]{2}{*}{ tot } \\
\hline & bottom & ref. & INTRU & QTZ & DOL & on) & CL) & VOLC & POM & METAM & \\
\hline 19.55 & 20.65 & 20.10 & 0 & 0 & 0 & 1 & 0 & 11 & 0 & 0 & 12 \\
\hline 24.17 & 25.02 & 24.60 & 0 & 0 & 0 & 0 & 0 & 0 & 0 & 0 & 0 \\
\hline 25.12 & 26.26 & 25.69 & 0 & 0 & 0 & 0 & 0 & 0 & 0 & 0 & 0 \\
\hline 26.40 & 27.40 & 26.90 & 0 & 2 & 0 & 34 & 0 & 6 & 0 & 0 & 42 \\
\hline 27.40 & 28.29 & 27.85 & 1 & 0 & 0 & 9 & 0 & 27 & 0 & 0 & 37 \\
\hline 28.32 & 29.15 & 28.74 & 0 & 3 & 0 & 4 & 0 & 28 & 0 & 0 & 35 \\
\hline 29.57 & 29.87 & 29.72 & 0 & 0 & 0 & 0 & 0 & 6 & 0 & 2 & 8 \\
\hline 30.11 & 31.11 & 30.61 & 1 & 4 & 0 & 6 & 0 & 74 & 0 & 0 & 85 \\
\hline 31.11 & 32.11 & 31.61 & 0 & 7 & 0 & 2 & 0 & 58 & 0 & 0 & 67 \\
\hline 32.11 & 33.31 & 32.71 & 0 & 5 & 0 & 3 & 0 & 53 & 0 & 1 & 62 \\
\hline 33.36 & 34.36 & 33.86 & 0 & 5 & 0 & 3 & 0 & 31 & 0 & 1 & 40 \\
\hline 34.36 & 35.36 & 34.86 & 0 & 15 & 0 & 3 & 0 & 49 & 0 & 6 & 73 \\
\hline 35.36 & 35.96 & 35.66 & 0 & 5 & 0 & 1 & 0 & 57 & 0 & 4 & 67 \\
\hline 36.11 & 37.11 & 36.61 & 0 & 5 & 0 & 2 & 0 & 50 & 0 & 2 & 59 \\
\hline 37.11 & 38.11 & 37.61 & 1 & 9 & 1 & 0 & 0 & 31 & 0 & 2 & 44 \\
\hline 38.11 & 39.11 & 38.61 & 0 & 5 & 3 & 0 & 0 & 30 & 0 & 1 & 39 \\
\hline 39.11 & 39.48 & 39.30 & 0 & 0 & 0 & 0 & 3 & 4 & 1 & 2 & 10 \\
\hline 40.30 & 41.30 & 40.80 & 3 & 4 & 0 & 0 & 5 & 47 & 2 & 3 & 64 \\
\hline 41.30 & 41.80 & 41.55 & 0 & 0 & 1 & 3 & 12 & 29 & 0 & 4 & 49 \\
\hline 41.88 & 42.88 & 42.38 & 0 & 7 & 5 & 5 & 0 & 24 & 0 & 0 & 41 \\
\hline 42.88 & 43.75 & 43.32 & 0 & 4 & 2 & 5 & 0 & 47 & 0 & 5 & 63 \\
\hline 43.75 & 44.73 & 44.24 & 5 & 0 & 1 & 34 & 0 & 31 & 0 & 6 & 77 \\
\hline 44.73 & 45.73 & 45.23 & 10 & 1 & 0 & 22 & 0 & 28 & 0 & 6 & 67 \\
\hline 45.73 & 46.73 & 46.23 & 5 & 2 & 2 & 59 & 0 & 18 & 0 & 5 & 91 \\
\hline 46.73 & 47.73 & 47.23 & 5 & 5 & 5 & 40 & 0 & 17 & 0 & 4 & 76 \\
\hline 47.73 & 48.73 & 48.23 & 12 & 3 & 1 & 15 & 0 & 49 & 0 & 2 & 82 \\
\hline 48.73 & 49.73 & 49.23 & 2 & 9 & 0 & 38 & 0 & 31 & 0 & 2 & 82 \\
\hline 49.73 & 50.77 & 50.25 & 10 & 3 & 1 & 9 & 0 & 100 & 0 & 1 & 124 \\
\hline 50.77 & 51.29 & 51.03 & 3 & 7 & 0 & 10 & 0 & 58 & 0 & 7 & 85 \\
\hline 52.61 & 53.71 & 53.16 & 25 & 6 & 3 & 8 & 0 & 102 & 0 & 41 & 185 \\
\hline 53.71 & 54.67 & 54.19 & 11 & 5 & 2 & 4 & 0 & 34 & 0 & 10 & 66 \\
\hline
\end{tabular}


Depht

$\begin{array}{ccc}\text { box } & \text { top } & \text { bottom } \\ 54.72 & 55.72 \\ 55.72 & 56.52 \\ 56.72 & 57.48 \\ 57.57 & 58.57 \\ 58.57 & 59.57 \\ 59.57 & 60.54 \\ 60.62 & 61.62 \\ 61.62 & 62.62 \\ 62.62 & 63.62 \\ 63.62 & 64.67 \\ 64.67 & 65.67 \\ 65.67 & 66.67 \\ 66.67 & 67.66 \\ 67.66 & 68.66 \\ 68.66 & 69.62 \\ 69.64 & 70.64 \\ 70.64 & 71.64 \\ 71.64 & 72.28 \\ 72.28 & 73.28 \\ 73.28 & 74.28 \\ 74.28 & 75.15 \\ 75.15 & 76.15 \\ 76.17 & 77.17 \\ 77.17 & 78.06 \\ 78.17 & 79.17 \\ 79.17 & 80.17 \\ 80.17 & 80.89 \\ 80.89 & 81.89 \\ 81.89 & 82.89 \\ 82.89 & 83.84 \\ 83.84 & 84.92 \\ 84.92 & 85.92 \\ 85.92 & 86.92 \\ 86.92 & 87.92 \\ 87.92 & 88.92 \\ 88.92 & 89.92 \\ & \\ & \end{array}$

NUMBER of CLASTS PER LITOLOGY

$\begin{array}{rr}\text { ref. } & \text { INTRU } \\ 55.22 & 0 \\ 56.12 & 3 \\ 57.10 & 6 \\ 58.07 & 5 \\ 59.07 & 7 \\ 60.06 & 12 \\ 61.12 & 8 \\ 62.12 & 16 \\ 63.12 & 18 \\ 64.15 & 12 \\ 65.17 & 18 \\ 66.17 & 10 \\ 67.17 & 21 \\ 68.16 & 33 \\ 69.14 & 13 \\ 70.14 & 8 \\ 71.14 & 3 \\ 71.96 & 5 \\ 72.78 & 11 \\ 73.78 & 14 \\ 74.72 & 13 \\ 75.65 & 15 \\ 76.67 & 19 \\ 77.62 & 7 \\ 78.67 & 15 \\ 79.67 & 18 \\ 80.53 & 11 \\ 81.39 & 26 \\ 82.39 & 7 \\ 83.37 & 0 \\ 84.38 & 1 \\ 85.42 & 0 \\ 86.42 & 0 \\ 87.42 & 2 \\ 88.42 & 0 \\ 89.42 & 0\end{array}$

QTZ
2
4
1
7
3
3
9
16
8
6
11
9
3
1
3
6
10
14
9
8
6
26
8
8
8
10
19
5
4
0
0
0
0
3
1
0

$\begin{array}{crrr}\text { DOL ts+Beacon) (INTRACL) } & \text { VOLC } \\ 2 & 3 & 0 & 17 \\ 0 & 21 & 0 & 7 \\ 2 & 16 & 0 & 13 \\ 0 & 7 & 0 & 25 \\ 2 & 31 & 0 & 20 \\ 5 & 21 & 0 & 19 \\ 1 & 7 & 0 & 26 \\ 3 & 14 & 0 & 48 \\ 0 & 14 & 0 & 43 \\ 2 & 7 & 0 & 15 \\ 2 & 11 & 0 & 25 \\ 3 & 9 & 0 & 16 \\ 1 & 13 & 0 & 9 \\ 2 & 17 & 0 & 9 \\ 1 & 3 & 0 & 0 \\ 5 & 8 & 0 & 8 \\ 0 & 11 & 0 & 20 \\ 2 & 5 & 0 & 12 \\ 4 & 12 & 0 & 11 \\ 0 & 7 & 0 & 17 \\ 0 & 4 & 0 & 14 \\ 1 & 17 & 44 & 20 \\ 0 & 4 & 12 & 6 \\ 0 & 18 & 26 & 11 \\ 0 & 23 & 31 & 8 \\ 1 & 7 & 18 & 16 \\ 0 & 9 & 28 & 5 \\ 0 & 16 & 21 & 23 \\ 0 & 13 & 17 & 50 \\ 0 & 0 & 19 & 19 \\ 0 & 1 & 0 & 10 \\ 0 & 0 & 0 & 0 \\ 0 & 0 & 0 & 9 \\ 0 & 6 & 0 & 71 \\ 0 & 4 & 0 & 54 \\ 0 & 0 & 0 & 46\end{array}$

$\begin{array}{rrr}\text { POM } & \text { METAM } & \text { tot } \\ 0 & 18 & 42 \\ 0 & 11 & 46 \\ 0 & 11 & 49 \\ 0 & 12 & 56 \\ 0 & 8 & 71 \\ 0 & 7 & 67 \\ 0 & 10 & 61 \\ 0 & 5 & 102 \\ 0 & 15 & 98 \\ 0 & 24 & 66 \\ 0 & 12 & 79 \\ 0 & 37 & 84 \\ 0 & 25 & 72 \\ 0 & 21 & 83 \\ 0 & 20 & 40 \\ 0 & 21 & 56 \\ 0 & 18 & 62 \\ 0 & 10 & 48 \\ 0 & 14 & 61 \\ 0 & 23 & 69 \\ 0 & 16 & 53 \\ 0 & 11 & 134 \\ 0 & 20 & 69 \\ 0 & 18 & 88 \\ 0 & 21 & 106 \\ 0 & 12 & 82 \\ 0 & 19 & 91 \\ 0 & 8 & 99 \\ 0 & 3 & 94 \\ 0 & 0 & 38 \\ 0 & 2 & 14 \\ 0 & 0 & 0 \\ 0 & 0 & 9 \\ 0 & 0 & 82 \\ 0 & 2 & 61 \\ 0 & 0 & 46\end{array}$


Depht

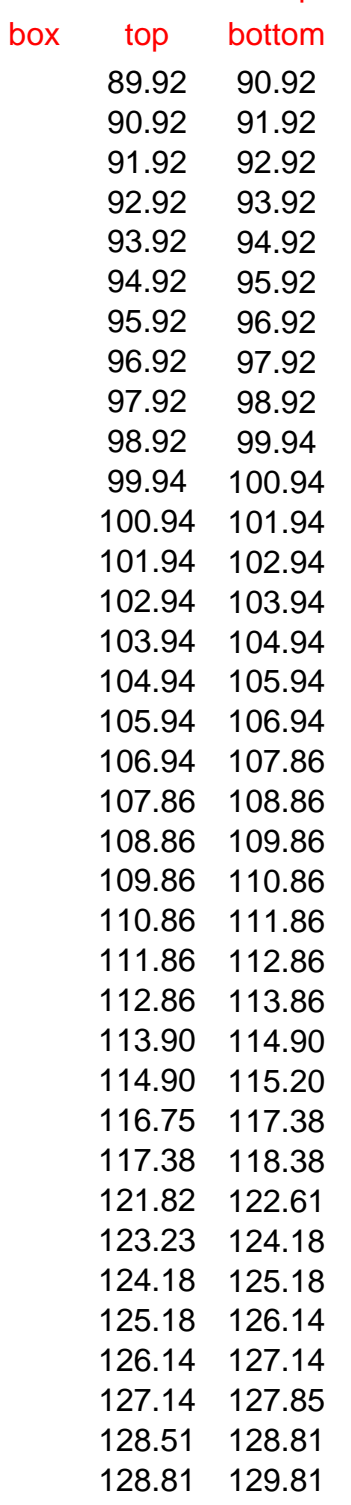

$\begin{array}{rr}\text { ref. } & \text { INTRU } \\ 90.42 & 0 \\ 91.42 & 0 \\ 92.42 & 0 \\ 93.42 & 0 \\ 94.42 & 0 \\ 95.42 & 0 \\ 96.42 & 1 \\ 97.42 & 1 \\ 98.42 & 7 \\ 99.43 & 3 \\ 100.44 & 0 \\ 101.44 & 1 \\ 102.44 & 2 \\ 103.44 & 3 \\ 104.44 & 7 \\ 105.44 & 8 \\ 106.44 & 4 \\ 107.40 & 0 \\ 108.36 & 3 \\ 109.36 & 0 \\ 110.36 & 0 \\ 111.36 & 0 \\ 112.36 & 0 \\ 113.36 & 0 \\ 114.40 & 0 \\ 115.05 & 0 \\ 117.07 & 0 \\ 117.88 & 0 \\ 122.22 & 2 \\ 123.71 & 6 \\ 124.68 & 3 \\ 125.66 & 0 \\ 126.64 & 7 \\ 127.50 & 0 \\ 128.66 & 1 \\ 129.31 & 0\end{array}$

NUMBER of CLASTS PER LITOLOGY

$\begin{array}{crrr}\text { DOL ts+Beacon) } & \text { (INTRACL) } & \text { VOLC } \\ 0 & 10 & 0 & 16 \\ 0 & 0 & 0 & 81 \\ 0 & 8 & 0 & 65 \\ 0 & 0 & 0 & 115 \\ 0 & 0 & 0 & 221 \\ 0 & 0 & 0 & 1 \\ 0 & 4 & 0 & 27 \\ 1 & 4 & 0 & 23 \\ 0 & 4 & 0 & 53 \\ 0 & 1 & 0 & 15 \\ 0 & 7 & 0 & 35 \\ 0 & 24 & 0 & 49 \\ 0 & 6 & 6 & 75 \\ 0 & 2 & 4 & 64 \\ 2 & 0 & 0 & 63 \\ 0 & 23 & 2 & 47 \\ 1 & 10 & 0 & 29 \\ 0 & 3 & 18 & 12 \\ 0 & 9 & 0 & 42 \\ 1 & 1 & 7 & 15 \\ 0 & 1 & 0 & 10 \\ 0 & 0 & 2 & 20 \\ 0 & 0 & 0 & 86 \\ 0 & 0 & 0 & 27 \\ 0 & 0 & 0 & 0 \\ 0 & 0 & 0 & 0 \\ 0 & 0 & 0 & 37 \\ 0 & 0 & 0 & 31 \\ 0 & 6 & 0 & 19 \\ 0 & 12 & 0 & 57 \\ 0 & 13 & 0 & 103 \\ 0 & 0 & 0 & 9 \\ 1 & 0 & 0 & 15 \\ 0 & 0 & 0 & 0 \\ 0 & 0 & 0 & 13 \\ 0 & 0 & 0 & 1\end{array}$

$\begin{array}{rrr}\text { POM } & \text { METAM } & \text { tot } \\ 0 & 0 & 26 \\ 0 & 0 & 81 \\ 0 & 0 & 74 \\ 0 & 0 & 115 \\ 0 & 0 & 221 \\ 0 & 0 & 1 \\ 0 & 18 & 50 \\ 0 & 5 & 35 \\ 0 & 15 & 84 \\ 0 & 0 & 20 \\ 0 & 2 & 46 \\ 0 & 16 & 90 \\ 0 & 10 & 106 \\ 0 & 10 & 84 \\ 0 & 22 & 103 \\ 0 & 7 & 91 \\ 0 & 1 & 46 \\ 0 & 1 & 34 \\ 0 & 2 & 59 \\ 0 & 1 & 26 \\ 0 & 0 & 11 \\ 0 & 5 & 27 \\ 0 & 0 & 86 \\ 0 & 0 & 27 \\ 0 & 0 & 0 \\ 0 & 0 & 0 \\ 0 & 0 & 37 \\ 0 & 2 & 33 \\ 0 & 1 & 33 \\ 0 & 4 & 96 \\ 0 & 28 & 157 \\ 0 & 2 & 15 \\ 0 & 7 & 36 \\ 0 & 0 & 0 \\ 0 & 1 & 15 \\ 0 & 0 & 1 \\ & & \end{array}$


Depht

\begin{tabular}{|c|c|}
\hline top & bottom \\
\hline 129.81 & 130.81 \\
\hline 130.81 & 131.81 \\
\hline 131.81 & 132.81 \\
\hline 132.81 & 133.80 \\
\hline 133.80 & 134.80 \\
\hline 135.16 & 136.16 \\
\hline 136.16 & 145.16 \\
\hline 145.16 & 146.17 \\
\hline 146.17 & 147.17 \\
\hline 147.17 & 148.10 \\
\hline 148.10 & 149.10 \\
\hline 149.10 & 150.10 \\
\hline 150.10 & 151.05 \\
\hline 151.05 & 152.05 \\
\hline 152.05 & 153.05 \\
\hline 153.05 & 154.05 \\
\hline 154.05 & 155.05 \\
\hline 155.05 & 156.05 \\
\hline 156.05 & 156.76 \\
\hline 157.71 & 158.71 \\
\hline 158.71 & 159.37 \\
\hline 160.19 & 161.98 \\
\hline 161.98 & 163.00 \\
\hline 163.00 & 164.00 \\
\hline 164.00 & 165.00 \\
\hline 165.00 & 165.30 \\
\hline 165.41 & 166.41 \\
\hline 166.41 & 167.41 \\
\hline 167.41 & 168.41 \\
\hline 168.41 & 169.41 \\
\hline 169.41 & 170.41 \\
\hline 170.41 & 171.31 \\
\hline 171.31 & 172.31 \\
\hline 172.31 & 173.31 \\
\hline 173.31 & 174.31 \\
\hline 174.45 & 175.45 \\
\hline
\end{tabular}

$\begin{array}{rrr}\text { ref. } & \text { INTRU } & \text { QTZ } \\ 130.31 & 0 & 1 \\ 131.31 & 0 & 0 \\ 132.31 & 0 & 0 \\ 133.31 & 0 & 0 \\ 134.30 & 8 & 1 \\ 135.66 & 0 & 0 \\ 140.66 & 0 & 0 \\ 145.67 & 0 & 1 \\ 146.67 & 8 & 17 \\ 147.64 & 9 & 12 \\ 148.60 & 2 & 4 \\ 149.60 & 3 & 4 \\ 150.58 & 4 & 5 \\ 151.55 & 1 & 0 \\ 152.55 & 0 & 0 \\ 153.55 & 0 & 0 \\ 154.55 & 0 & 0 \\ 155.55 & 0 & 0 \\ 156.41 & 0 & 0 \\ 158.21 & 0 & 0 \\ 159.04 & 0 & 0 \\ 161.09 & 16 & 0 \\ 162.49 & 5 & 0 \\ 163.50 & 2 & 2 \\ 164.50 & 1 & 1 \\ 165.15 & 0 & 0 \\ 165.91 & 0 & 0 \\ 166.91 & 0 & 0 \\ 167.91 & 0 & 0 \\ 168.91 & 5 & 0 \\ 169.91 & 1 & 0 \\ 170.86 & 0 & 0 \\ 171.81 & 0 & 0 \\ 172.81 & 0 & 0 \\ 173.81 & 0 & 0 \\ 174.95 & 0 & 0\end{array}$

NUMBER of CLASTS PER LITOLOGY

$\begin{array}{ccrr}\text { DOL ts+Beacon) } & \text { (INTRACL) } & \text { VOLC } \\ 0 & 0 & 0 & 0 \\ 0 & 0 & 0 & 0 \\ 0 & 0 & 0 & 4 \\ 0 & 0 & 0 & 0 \\ 0 & 2 & 0 & 6 \\ 0 & 0 & 0 & 0 \\ 0 & 0 & 0 & 0 \\ 0 & 0 & 0 & 4 \\ 0 & 2 & 0 & 8 \\ 0 & 2 & 0 & 63 \\ 0 & 7 & 0 & 141 \\ 0 & 6 & 0 & 126 \\ 0 & 1 & 0 & 47 \\ 0 & 0 & 0 & 34 \\ 0 & 0 & 0 & 24 \\ 0 & 0 & 0 & 25 \\ 0 & 0 & 0 & 34 \\ 0 & 0 & 0 & 48 \\ 0 & 0 & 0 & 61 \\ 0 & 0 & 0 & 5 \\ 0 & 0 & 0 & 10 \\ 0 & 1 & 0 & 37 \\ 0 & 8 & 0 & 32 \\ 0 & 6 & 0 & 23 \\ 0 & 6 & 0 & 27 \\ 0 & 0 & 0 & 14 \\ 0 & 0 & 0 & 9 \\ 0 & 0 & 0 & 9 \\ 0 & 0 & 0 & 33 \\ 0 & 3 & 0 & 33 \\ 0 & 0 & 0 & 13 \\ 0 & 0 & 0 & 0 \\ 0 & 0 & 0 & 0 \\ 0 & 0 & 0 & 0 \\ 0 & 0 & 0 & 5 \\ 0 & 0 & 0 & 6\end{array}$

$\begin{array}{rrr}\text { POM } & \text { METAM } & \text { tot } \\ 0 & 0 & 1 \\ 0 & 0 & 0 \\ 0 & 0 & 4 \\ 0 & 0 & 0 \\ 0 & 11 & 28 \\ 0 & 0 & 0 \\ 0 & 0 & 0 \\ 0 & 0 & 5 \\ 0 & 69 & 104 \\ 0 & 62 & 148 \\ 0 & 24 & 178 \\ 0 & 59 & 198 \\ 0 & 73 & 130 \\ 0 & 0 & 35 \\ 0 & 0 & 24 \\ 0 & 0 & 25 \\ 0 & 2 & 36 \\ 0 & 4 & 52 \\ 0 & 9 & 70 \\ 0 & 1 & 6 \\ 0 & 0 & 10 \\ 0 & 33 & 87 \\ 0 & 41 & 86 \\ 0 & 70 & 103 \\ 0 & 39 & 74 \\ 0 & 1 & 15 \\ 0 & 0 & 9 \\ 0 & 0 & 9 \\ 0 & 6 & 39 \\ 0 & 24 & 65 \\ 0 & 6 & 20 \\ 0 & 0 & 0 \\ 0 & 0 & 0 \\ 0 & 0 & 0 \\ 0 & 1 & 6 \\ 0 & 5 & 11 \\ & & \end{array}$




\section{Depht}

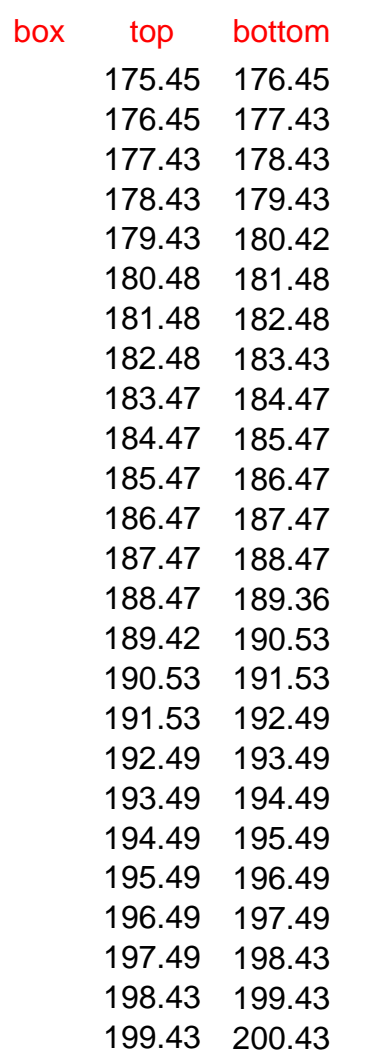

$\begin{array}{crr}\text { ref. } & \text { INTRU } & \text { QTZ } \\ 175.95 & 0 & 0 \\ 176.94 & 0 & 0 \\ 177.93 & 0 & 0 \\ 178.93 & 0 & 0 \\ 179.93 & 0 & 0 \\ 180.98 & 0 & 0 \\ 181.98 & 5 & 4 \\ 182.96 & 5 & 1 \\ 183.97 & 0 & 0 \\ 184.97 & 0 & 0 \\ 185.97 & 4 & 1 \\ 186.97 & 6 & 2 \\ 187.97 & 5 & 7 \\ 188.92 & 0 & 5 \\ 189.98 & 2 & 0 \\ 191.03 & 4 & 1 \\ 192.01 & 0 & 0 \\ 192.99 & 0 & 0 \\ 193.99 & 0 & 0 \\ 194.99 & 0 & 0 \\ 195.99 & 0 & 0 \\ 196.99 & 0 & 0 \\ 197.96 & 0 & 0 \\ 198.93 & 0 & 0 \\ 199.93 & 0 & 0 \\ \sim \sim \sim & \\ \text { OTALI } & 606 & 499\end{array}$

NUMBER of CLASTS PER LITOLOGY

$\begin{array}{crrrrrr}\text { DOL ts+Beacon) } & \text { (INTRACL) } & \text { VOLC } & \text { POM } & \text { METAM } & \text { tot } \\ 0 & 0 & 0 & 5 & 0 & 4 & 9 \\ 0 & 0 & 0 & 7 & 0 & 2 & 9 \\ 0 & 0 & 0 & 35 & 0 & 27 & 62 \\ 0 & 0 & 0 & 50 & 0 & 13 & 63 \\ 0 & 0 & 0 & 8 & 0 & 2 & 10 \\ 0 & 1 & 0 & 2 & 0 & 4 & 7 \\ 0 & 5 & 0 & 25 & 0 & 84 & 123 \\ 0 & 7 & 0 & 21 & 0 & 72 & 106 \\ 0 & 0 & 0 & 0 & 0 & 2 & 2 \\ 0 & 4 & 0 & 42 & 0 & 81 & 127 \\ 0 & 13 & 0 & 16 & 0 & 101 & 135 \\ 0 & 17 & 0 & 118 & 0 & 5 & 148 \\ 0 & 14 & 0 & 89 & 0 & 5 & 120 \\ 0 & 4 & 0 & 111 & 0 & 0 & 120 \\ 0 & 7 & 0 & 78 & 0 & 0 & 87 \\ 0 & 2 & 0 & 56 & 0 & 10 & 73 \\ 0 & 0 & 0 & 28 & 0 & 15 & 43 \\ 0 & 1 & 0 & 60 & 0 & 1 & 62 \\ 0 & 0 & 0 & 42 & 0 & 2 & 44 \\ 0 & 0 & 0 & 20 & 0 & 0 & 20 \\ 0 & 0 & 0 & 46 & 0 & 0 & 46 \\ 0 & 0 & 0 & 23 & 0 & 0 & 23 \\ 0 & 0 & 0 & 19 & 0 & 0 & 19 \\ 0 & 0 & 0 & 8 & 0 & 0 & 8 \\ 0 & 0 & 0 & 1 & 0 & 0 & 1 \\ 72 & 946 & 275 & 5119 & 01701 & 9221\end{array}$


MIS CORE - MODAL VARIATIONS IN CLAST LITHOLOGIES 200-300 MBSF

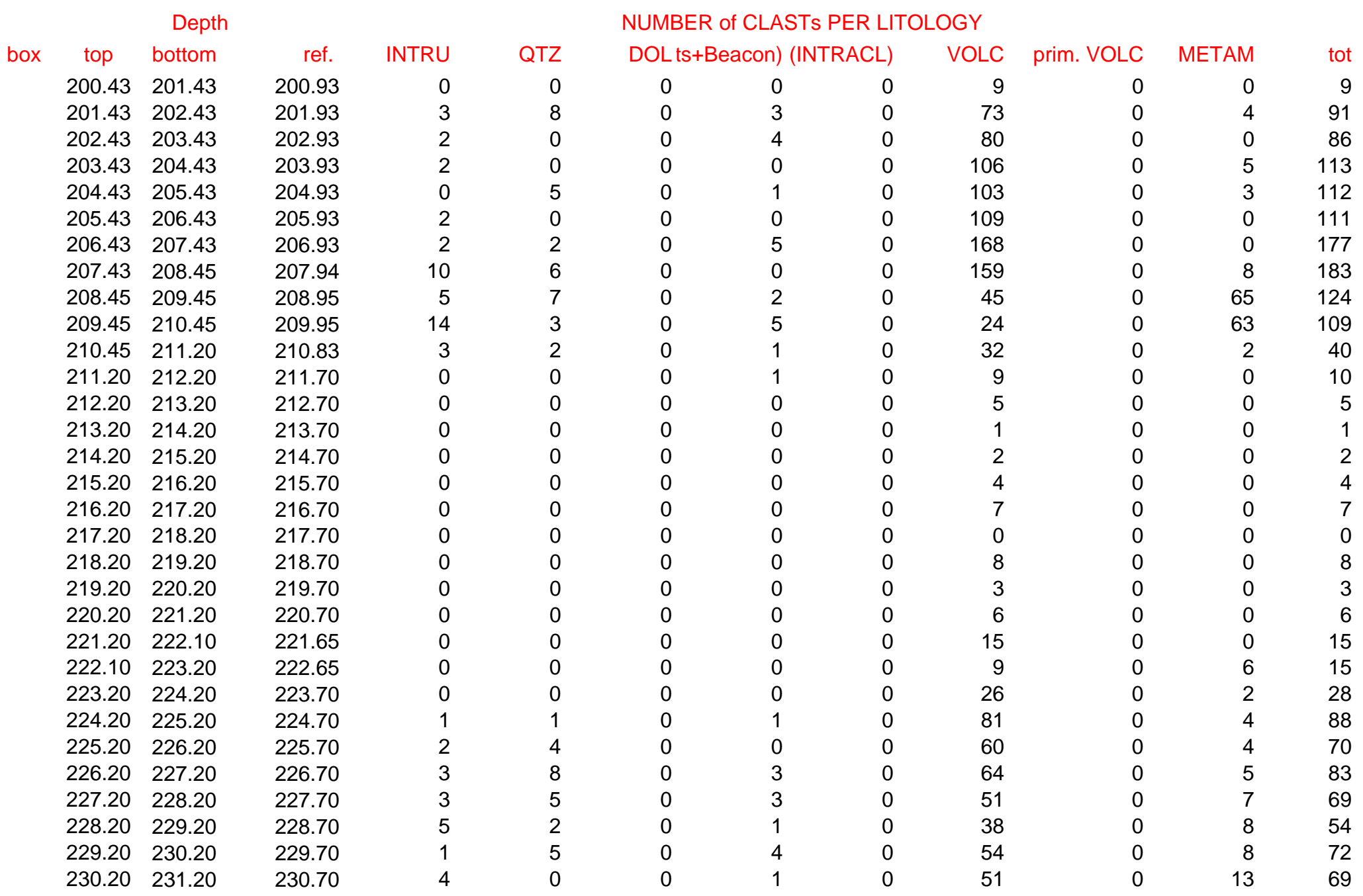


Depth

\begin{tabular}{|c|c|}
\hline top & bottom \\
\hline 231.20 & 232.20 \\
\hline 232.20 & 233.20 \\
\hline 233.20 & 234.18 \\
\hline 234.18 & 235.94 \\
\hline 235.94 & 236.94 \\
\hline 236.94 & 237.94 \\
\hline 238.04 & 239.04 \\
\hline 239.04 & 240.04 \\
\hline 240.04 & 241.04 \\
\hline 241.04 & 242.04 \\
\hline 242.04 & 243.07 \\
\hline 243.71 & 244.63 \\
\hline 244.63 & 245.63 \\
\hline 245.63 & 246.63 \\
\hline 246.63 & 247.63 \\
\hline 247.63 & 248.63 \\
\hline 248.63 & 249.45 \\
\hline 249.53 & 250.53 \\
\hline 250.53 & 251.53 \\
\hline 251.53 & 252.53 \\
\hline 252.53 & 253.53 \\
\hline 253.53 & 254.53 \\
\hline 254.53 & 255.53 \\
\hline 255.53 & 256.53 \\
\hline 256.53 & 257.53 \\
\hline 257.53 & 258.53 \\
\hline 258.53 & 259.53 \\
\hline 259.53 & 260.53 \\
\hline 260.53 & 261.44 \\
\hline 261.44 & 262.44 \\
\hline 262.44 & 263.44 \\
\hline 263.44 & 264.44 \\
\hline 264.44 & 265.44 \\
\hline 265.44 & 266.44 \\
\hline 266.44 & 267.44 \\
\hline 267.44 & 268.44 \\
\hline
\end{tabular}

$\begin{array}{rrr}\text { ref. } & \text { INTRU } & \text { QTZ } \\ 231.70 & 1 & 0 \\ 232.70 & 2 & 1 \\ 233.69 & 3 & 4 \\ 235.06 & 2 & 3 \\ 236.44 & 1 & 4 \\ 237.44 & 2 & 7 \\ 238.54 & 3 & 5 \\ 239.54 & 4 & 5 \\ 240.54 & 1 & 0 \\ 241.54 & 2 & 10 \\ 242.56 & 3 & 4 \\ 244.17 & 1 & 4 \\ 245.13 & 1 & 5 \\ 246.13 & 6 & 1 \\ 247.13 & 3 & 6 \\ 248.13 & 4 & 4 \\ 249.04 & 0 & 3 \\ 250.03 & 3 & 4 \\ 251.03 & 3 & 4 \\ 252.03 & 4 & 2 \\ 253.03 & 0 & 0 \\ 254.03 & 0 & 0 \\ 255.03 & 0 & 0 \\ 256.03 & 0 & 0 \\ 257.03 & 0 & 0 \\ 258.03 & 0 & 0 \\ 259.03 & 3 & 4 \\ 260.03 & 0 & 0 \\ 260.99 & 2 & 4 \\ 261.94 & 0 & 0 \\ 262.94 & 1 & 2 \\ 263.94 & 4 & 4 \\ 264.94 & 0 & 0 \\ 265.94 & 4 & 5 \\ 266.94 & 5 & 3 \\ 267.94 & 0 & 0\end{array}$

NUMBER of CLASTS PER LITOLOGY

\begin{tabular}{|c|c|c|c|c|c|c|}
\hline \multicolumn{3}{|c|}{ DOL ts+Beacon) (INTRACL) } & VOLC & prim. VOLC & METAM & tot \\
\hline 0 & 3 & 0 & 15 & 0 & 2 & 21 \\
\hline 0 & 9 & 0 & 35 & 0 & 2 & 49 \\
\hline 0 & 3 & 0 & 43 & 0 & 3 & 56 \\
\hline 0 & 0 & 0 & 36 & 0 & 3 & 44 \\
\hline 0 & 0 & 0 & 35 & 0 & 4 & 44 \\
\hline 0 & 0 & 0 & 108 & 0 & 7 & 124 \\
\hline 0 & 0 & 0 & 125 & 0 & 80 & 213 \\
\hline 0 & 1 & 0 & 95 & 0 & 12 & 117 \\
\hline 0 & 2 & 0 & 82 & 0 & 24 & 109 \\
\hline 0 & 2 & 0 & 101 & 0 & 14 & 129 \\
\hline 1 & 3 & 0 & 71 & 0 & 3 & 85 \\
\hline 0 & 0 & 0 & 59 & 0 & 3 & 67 \\
\hline 0 & 4 & 0 & 72 & 0 & 13 & 95 \\
\hline 0 & 0 & 0 & 68 & 0 & 11 & 86 \\
\hline 0 & 2 & 0 & 54 & 0 & 2 & 67 \\
\hline 0 & 3 & 0 & 65 & 0 & 23 & 99 \\
\hline 0 & 3 & 0 & 22 & 0 & 7 & 35 \\
\hline 0 & 1 & 0 & 44 & 0 & 5 & 57 \\
\hline 0 & 7 & 0 & 77 & 0 & 16 & 107 \\
\hline 0 & 0 & 0 & 21 & 0 & 23 & 50 \\
\hline 0 & 0 & 0 & 8 & 0 & 0 & 8 \\
\hline 0 & 0 & 0 & 2 & 0 & 2 & 4 \\
\hline 0 & 0 & 0 & 7 & 0 & 0 & 7 \\
\hline 0 & 1 & 0 & 15 & 0 & 0 & 16 \\
\hline 0 & 1 & 0 & 16 & 0 & 0 & 17 \\
\hline 0 & 0 & 0 & 18 & 0 & 0 & 18 \\
\hline 0 & 0 & 0 & 11 & 0 & 8 & 26 \\
\hline 0 & 0 & 0 & 0 & 0 & 7 & 7 \\
\hline 0 & 3 & 0 & 109 & 0 & 11 & 129 \\
\hline 1 & 3 & 0 & 72 & 0 & 7 & 83 \\
\hline 0 & 0 & 0 & 49 & 0 & 5 & 57 \\
\hline 0 & 0 & 0 & 50 & 0 & 3 & 61 \\
\hline 0 & 0 & 0 & 29 & 0 & 0 & 29 \\
\hline 0 & 0 & 0 & 65 & 0 & 7 & 81 \\
\hline 0 & 0 & 0 & 62 & 0 & 5 & 75 \\
\hline 0 & 0 & 0 & 4 & 0 & 2 & 6 \\
\hline
\end{tabular}


Depth

$\begin{array}{ccc}\text { box } & \text { top } & \text { bottom } \\ 268.44 & 269.44 \\ 269.44 & 270.44 \\ 270.44 & 271.44 \\ 271.44 & 272.44 \\ 272.44 & 273.40 \\ 273.40 & 274.40 \\ 274.40 & 275.40 \\ 275.40 & 276.40 \\ 276.40 & 277.40 \\ 277.40 & 278.40 \\ 278.40 & 279.40 \\ 279.40 & 280.40 \\ 280.40 & 281.40 \\ 281.40 & 282.40 \\ 282.40 & 283.40 \\ 283.40 & 284.40 \\ 284.40 & 285.40 \\ 285.40 & 286.40 \\ 286.40 & 287.40 \\ 287.40 & 288.40 \\ 288.40 & 289.40 \\ 289.40 & 290.40 \\ 290.40 & 291.40 \\ 291.40 & 292.44 \\ 292.44 & 293.29 \\ 295.46 & 296.46 \\ 296.46 & 297.46 \\ 297.46 & 298.46 \\ 298.46 & 299.46 \\ 299.46 & 300.45\end{array}$

$\begin{array}{rrr}\text { ref. } & \text { INTRU } & \text { QTZ } \\ 268.94 & 0 & 2 \\ 269.94 & 0 & 0 \\ 270.94 & 2 & 7 \\ 271.94 & 3 & 4 \\ 272.92 & 6 & 5 \\ 273.90 & 2 & 8 \\ 274.90 & 3 & 11 \\ 275.90 & 3 & 2 \\ 276.90 & 2 & 3 \\ 277.90 & 4 & 5 \\ 278.90 & 4 & 2 \\ 279.90 & 7 & 6 \\ 280.90 & 1 & 4 \\ 281.90 & 1 & 6 \\ 282.90 & 0 & 1 \\ 283.90 & 2 & 4 \\ 284.90 & 1 & 0 \\ 285.90 & 0 & 6 \\ 286.90 & 0 & 0 \\ 287.90 & 0 & 0 \\ 288.90 & 0 & 0 \\ 289.90 & 0 & 0 \\ 290.90 & 0 & 0 \\ 291.92 & 0 & 3 \\ 292.87 & 0 & 0 \\ 295.96 & 0 & 7 \\ 296.96 & 1 & 0 \\ 297.96 & 3 & 1 \\ 298.96 & 1 & 0 \\ 299.96 & 0 & 5 \\ \text { OTALI } & \\ & & \\ 248 & \end{array}$

NUMBER of CLASTS PER LITOLOGY

$\begin{array}{rrrrrrr}\text { DOL tS+Beacon) } & \text { (INTRACL) } & \text { VOLC } & \text { prim. VOLC } & \text { METAM } & \text { tot } \\ 0 & 0 & 0 & 13 & 0 & 2 & 17 \\ 0 & 6 & 0 & 79 & 0 & 4 & 89 \\ 0 & 4 & 0 & 77 & 0 & 0 & 90 \\ 0 & 0 & 0 & 53 & 0 & 1 & 61 \\ 0 & 5 & 0 & 89 & 0 & 4 & 109 \\ 0 & 3 & 0 & 85 & 0 & 8 & 106 \\ 0 & 4 & 0 & 107 & 0 & 7 & 132 \\ 0 & 3 & 0 & 123 & 0 & 2 & 133 \\ 0 & 1 & 0 & 96 & 0 & 3 & 105 \\ 1 & 3 & 0 & 95 & 0 & 6 & 114 \\ 0 & 0 & 0 & 119 & 0 & 7 & 132 \\ 0 & 4 & 0 & 140 & 0 & 5 & 162 \\ 2 & 6 & 0 & 110 & 0 & 4 & 127 \\ 0 & 1 & 0 & 119 & 0 & 8 & 135 \\ 0 & 2 & 0 & 15 & 0 & 1 & 19 \\ 0 & 1 & 0 & 35 & 0 & 0 & 42 \\ 0 & 5 & 0 & 60 & 0 & 0 & 66 \\ 0 & 0 & 0 & 31 & 0 & 2 & 39 \\ 0 & 0 & 0 & 22 & 0 & 0 & 22 \\ 0 & 0 & 0 & 17 & 0 & 0 & 17 \\ 0 & 0 & 0 & 11 & 0 & 1 & 12 \\ 0 & 0 & 0 & 37 & 0 & 0 & 37 \\ 0 & 0 & 0 & 10 & 0 & 0 & 10 \\ 0 & 0 & 0 & 59 & 0 & 0 & 62 \\ 0 & 0 & 0 & 0 & 0 & 0 & 0 \\ 0 & 0 & 0 & 181 & 0 & 0 & 219 \\ 0 & 0 & 0 & 124 & 0 & 0 & 131 \\ 0 & 0 & 0 & 60 & 0 & 0 & 67 \\ 0 & 0 & 0 & 66 & 0 & 0 & 48 \\ 0 & 0 & 0 & 43 & 0 & 0 & 6410\end{array}$


MIS CORE - MODAL VARIATIONS IN CLAST LITHOLOGIES

300-400 MBSF

\begin{tabular}{|c|c|c|c|c|c|c|c|c|c|c|c|}
\hline \multirow[b]{2}{*}{ box } & \multicolumn{2}{|l|}{ Depth } & \multicolumn{8}{|c|}{ NUMBER of CLASTS PER LITOLOGY } & \multirow[b]{2}{*}{ tot } \\
\hline & bottom & ref. & INTRU & QTZ & DOL & n) & & VOLC & POM & METAM & \\
\hline 300.45 & 301.45 & 300.95 & 1 & 4 & 0 & 0 & 0 & 28 & 0 & 4 & 37 \\
\hline 301.52 & 302.52 & 302.02 & 2 & 3 & 0 & 0 & 0 & 26 & 0 & 2 & 33 \\
\hline 302.52 & 303.52 & 303.02 & 0 & 1 & 0 & 0 & 0 & 46 & 0 & 0 & 47 \\
\hline 303.52 & 304.52 & 304.02 & 0 & 4 & 1 & 0 & 0 & 89 & 0 & 0 & 94 \\
\hline 304.52 & 305.52 & 305.02 & 0 & 5 & 0 & 0 & 0 & 93 & 0 & 3 & 101 \\
\hline 305.52 & 306.52 & 306.02 & 0 & 9 & 0 & 0 & 0 & 150 & 0 & 10 & 169 \\
\hline 306.52 & 307.52 & 307.02 & 0 & 6 & 0 & 0 & 0 & 90 & 0 & 4 & 100 \\
\hline 307.53 & 308.53 & 308.03 & 0 & 4 & 0 & 0 & 0 & 96 & 0 & 0 & 100 \\
\hline 308.53 & 309.53 & 309.03 & 0 & 1 & 0 & 2 & 0 & 83 & 0 & 10 & 96 \\
\hline 309.53 & 310.53 & 310.03 & 2 & 10 & 0 & 1 & 0 & 101 & 0 & 1 & 115 \\
\hline 310.53 & 311.53 & 311.03 & 5 & 7 & 0 & 0 & 0 & 106 & 0 & 0 & 118 \\
\hline 311.53 & 312.53 & 312.03 & 3 & 10 & 0 & 1 & 0 & 108 & 0 & 10 & 132 \\
\hline 312.53 & 313.54 & 313.04 & 6 & 4 & 0 & 0 & 0 & 106 & 0 & 8 & 124 \\
\hline 313.54 & 314.54 & 314.04 & 3 & 6 & 0 & 0 & 0 & 109 & 0 & 7 & 125 \\
\hline 314.54 & 315.54 & 315.04 & 10 & 5 & 0 & 0 & 0 & 84 & 0 & 13 & 112 \\
\hline 315.54 & 316.54 & 316.04 & 1 & 6 & 0 & 0 & 0 & 73 & 0 & 6 & 86 \\
\hline 316.54 & 317.54 & 317.04 & 7 & 5 & 0 & 0 & 0 & 64 & 0 & 2 & 78 \\
\hline 317.54 & 318.54 & 318.04 & 0 & 3 & 0 & 3 & 0 & 70 & 0 & 5 & 81 \\
\hline 318.54 & 319.54 & 319.04 & 5 & 7 & 0 & 1 & 0 & 61 & 0 & 7 & 81 \\
\hline 319.54 & 320.54 & 320.04 & 1 & 8 & 0 & 0 & 0 & 84 & 0 & 3 & 96 \\
\hline 320.54 & 321.54 & 321.04 & 2 & 6 & 0 & 3 & 0 & 71 & 0 & 16 & 98 \\
\hline 321.54 & 322.44 & 321.99 & 13 & 7 & 0 & 2 & 0 & 82 & 0 & 10 & 114 \\
\hline 322.54 & 323.54 & 323.04 & 2 & 2 & 0 & 0 & 0 & 110 & 0 & 0 & 114 \\
\hline 323.54 & 324.54 & 324.04 & 0 & 4 & 0 & 0 & 0 & 93 & 0 & 8 & 105 \\
\hline 324.54 & 325.49 & 325.02 & 2 & 2 & 0 & 0 & 0 & 63 & 0 & 11 & 78 \\
\hline 325.49 & 326.49 & 325.99 & 3 & 4 & 0 & 1 & 0 & 77 & 0 & 8 & 93 \\
\hline 326.49 & 327.49 & 326.99 & 2 & 3 & 0 & 1 & 0 & 68 & 0 & 0 & 74 \\
\hline 327.49 & 328.49 & 327.99 & 3 & 4 & 0 & 0 & 0 & 105 & 0 & 0 & 112 \\
\hline 328.49 & 329.49 & 328.99 & 3 & 6 & 0 & 0 & 0 & 70 & 0 & 9 & 88 \\
\hline 329.49 & 330.49 & 329.99 & 2 & 3 & 1 & 0 & 0 & 85 & 0 & 5 & 96 \\
\hline 330.49 & 331.49 & 330.99 & 0 & 2 & 0 & 2 & 0 & 78 & 0 & 11 & 93 \\
\hline
\end{tabular}


Depth

\begin{tabular}{|c|c|c|c|c|}
\hline top & bottom & ref. & INTRU & QTZ \\
\hline 331.49 & 332.49 & 331.99 & 3 & 3 \\
\hline 332.49 & 333.49 & 332.99 & 1 & 4 \\
\hline 333.49 & 334.49 & 333.99 & 2 & 4 \\
\hline 334.49 & 335.49 & 334.99 & 4 & 4 \\
\hline 335.49 & 336.49 & 335.99 & 2 & 4 \\
\hline 336.49 & 337.49 & 336.99 & 3 & 6 \\
\hline 337.49 & 338.49 & 337.99 & 1 & 2 \\
\hline 338.49 & 339.49 & 338.99 & 0 & 0 \\
\hline 339.49 & 340.49 & 339.99 & 0 & 0 \\
\hline 340.49 & 341.49 & 340.99 & 3 & 0 \\
\hline 341.49 & 342.49 & 341.99 & 2 & 4 \\
\hline 342.49 & 343.49 & 342.99 & 1 & 1 \\
\hline 343.49 & 344.49 & 343.99 & 0 & 2 \\
\hline 344.49 & 345.49 & 344.99 & 1 & 5 \\
\hline 345.49 & 346.49 & 345.99 & 0 & 0 \\
\hline 346.49 & 347.49 & 346.99 & 2 & 0 \\
\hline 347.49 & 348.49 & 347.99 & 0 & 1 \\
\hline 348.49 & 349.49 & 348.99 & 1 & 4 \\
\hline 349.49 & 350.49 & 349.99 & 1 & 1 \\
\hline 350.49 & 351.49 & 350.99 & 1 & 3 \\
\hline 351.49 & 352.49 & 351.99 & 1 & 0 \\
\hline 352.49 & 353.49 & 352.99 & 2 & 3 \\
\hline 353.49 & 354.41 & 353.95 & 0 & 0 \\
\hline 354.47 & 355.47 & 354.97 & 4 & 0 \\
\hline 355.47 & 356.47 & 355.97 & 0 & 0 \\
\hline 356.47 & 357.47 & 356.97 & 0 & 1 \\
\hline 357.47 & 358.47 & 357.97 & 0 & 0 \\
\hline 358.47 & 359.47 & 358.97 & 0 & 0 \\
\hline 359.47 & 360.42 & 359.95 & 0 & 0 \\
\hline 360.42 & 361.42 & 360.92 & 0 & 0 \\
\hline 361.42 & 362.42 & 361.92 & 1 & 0 \\
\hline 362.42 & 363.42 & 362.92 & 0 & 0 \\
\hline 363.42 & 364.42 & 363.92 & 1 & 6 \\
\hline 364.42 & 365.42 & 364.92 & 0 & 0 \\
\hline 365.42 & 366.42 & 365.92 & 2 & 9 \\
\hline 366.55 & 367.55 & 367.05 & 0 & 5 \\
\hline
\end{tabular}

NUMBER of CLASTS PER LITOLOGY

\begin{tabular}{|c|c|c|c|}
\hline \multicolumn{3}{|c|}{ DOL ts+Beacon) (INTRACL) } & \multirow{2}{*}{$\begin{array}{r}\text { VOLC } \\
81\end{array}$} \\
\hline 0 & 0 & 0 & \\
\hline 0 & 2 & 0 & 75 \\
\hline 0 & 0 & 0 & 83 \\
\hline 1 & 0 & 0 & 88 \\
\hline 0 & 3 & 0 & 71 \\
\hline 0 & 1 & 0 & 78 \\
\hline 0 & 2 & 0 & 89 \\
\hline 0 & 0 & 0 & 92 \\
\hline 0 & 0 & 0 & 102 \\
\hline 0 & 1 & 0 & 0 \\
\hline 0 & 2 & 0 & 72 \\
\hline 0 & 1 & 0 & 91 \\
\hline 0 & 0 & 0 & 86 \\
\hline 2 & 1 & 0 & 82 \\
\hline 0 & 1 & 0 & 83 \\
\hline 0 & 0 & 0 & 37 \\
\hline 0 & 2 & 0 & 3 \\
\hline 0 & 3 & 0 & 65 \\
\hline 0 & 7 & 0 & 127 \\
\hline 0 & 12 & 0 & 0 \\
\hline 0 & 6 & 0 & 22 \\
\hline 0 & 0 & 0 & 65 \\
\hline 0 & 0 & 0 & 1 \\
\hline 0 & 1 & 0 & 43 \\
\hline 0 & 1 & 0 & 65 \\
\hline 0 & 1 & 0 & 113 \\
\hline 0 & 0 & 0 & 24 \\
\hline 0 & 0 & 0 & 10 \\
\hline 0 & 0 & 0 & 9 \\
\hline 0 & 0 & 0 & 22 \\
\hline 0 & 0 & 0 & 112 \\
\hline 0 & 2 & 0 & 9 \\
\hline 0 & 6 & 0 & 86 \\
\hline 0 & 3 & 0 & 72 \\
\hline 0 & 1 & 0 & 76 \\
\hline 0 & 2 & 0 & 82 \\
\hline
\end{tabular}

$\begin{array}{rrr}\text { POM } & \text { METAM } & \text { tot } \\ 0 & 1 & 88 \\ 0 & 1 & 83 \\ 0 & 1 & 90 \\ 0 & 3 & 100 \\ 0 & 4 & 84 \\ 0 & 4 & 92 \\ 0 & 1 & 95 \\ 0 & 2 & 94 \\ 0 & 1 & 103 \\ 0 & 1 & 5 \\ 0 & 3 & 83 \\ 0 & 4 & 98 \\ 0 & 3 & 91 \\ 0 & 3 & 94 \\ 0 & 0 & 84 \\ 0 & 0 & 39 \\ 0 & 0 & 6 \\ 0 & 0 & 73 \\ 0 & 1 & 137 \\ 0 & 0 & 16 \\ 0 & 0 & 29 \\ 0 & 0 & 70 \\ 0 & 0 & 1 \\ 0 & 0 & 48 \\ 0 & 0 & 66 \\ 0 & 2 & 117 \\ 0 & 0 & 24 \\ 0 & 0 & 10 \\ 0 & 0 & 9 \\ 0 & 0 & 22 \\ 0 & 0 & 113 \\ 0 & 0 & 11 \\ 0 & 3 & 102 \\ 0 & 1 & 76 \\ 0 & 4 & 92 \\ 0 & 4 & 93\end{array}$


Depth

\begin{tabular}{|c|c|c|}
\hline box & top & bottom \\
\hline & 367.55 & 368.55 \\
\hline & 368.55 & 369.55 \\
\hline & 369.55 & 370.55 \\
\hline & 370.55 & 371.55 \\
\hline & 371.55 & 372.55 \\
\hline & 372.55 & 373.55 \\
\hline & 373.55 & 374.55 \\
\hline & 374.55 & 375.55 \\
\hline & 375.55 & 376.55 \\
\hline & 376.55 & 377.55 \\
\hline & 377.55 & 378.55 \\
\hline & 378.55 & 379.55 \\
\hline & 379.55 & 380.55 \\
\hline & 380.55 & 381.55 \\
\hline & 381.55 & 382.55 \\
\hline & 382.55 & 383.55 \\
\hline & 383.55 & 384.55 \\
\hline & 384.55 & 385.55 \\
\hline & 385.55 & 386.55 \\
\hline & 386.55 & 387.55 \\
\hline & 387.55 & 388.55 \\
\hline & 388.55 & 389.55 \\
\hline & 389.55 & 390.55 \\
\hline & 390.55 & 391.55 \\
\hline & 391.55 & 392.55 \\
\hline & 392.55 & 393.55 \\
\hline & 393.55 & 394.55 \\
\hline & 394.55 & 395.55 \\
\hline & 395.55 & 396.55 \\
\hline & 396.55 & 397.55 \\
\hline & 397.55 & 398.55 \\
\hline & 398.55 & 399.55 \\
\hline & 399.55 & 400.55 \\
\hline
\end{tabular}

\begin{tabular}{|c|c|c|}
\hline ref. & INTRU & QTZ \\
\hline 368.05 & 4 & 4 \\
\hline 369.05 & 3 & 1 \\
\hline 370.05 & 3 & 11 \\
\hline 371.05 & 2 & 4 \\
\hline 372.05 & 2 & 8 \\
\hline 373.05 & 4 & 6 \\
\hline 374.05 & 2 & 0 \\
\hline 375.05 & 3 & 4 \\
\hline 376.05 & 3 & 3 \\
\hline 377.05 & 1 & 0 \\
\hline 378.05 & 0 & 0 \\
\hline 379.05 & 0 & 0 \\
\hline 380.05 & 2 & 0 \\
\hline 381.05 & 2 & 1 \\
\hline 382.05 & 6 & 4 \\
\hline 383.05 & 0 & 0 \\
\hline 384.05 & 0 & 0 \\
\hline 385.05 & 0 & 0 \\
\hline 386.05 & 2 & 0 \\
\hline 387.05 & 0 & 1 \\
\hline 388.05 & 0 & 0 \\
\hline 389.05 & 0 & 0 \\
\hline 390.05 & 0 & 0 \\
\hline 391.05 & 0 & 0 \\
\hline 392.05 & 0 & 0 \\
\hline 393.05 & 0 & 0 \\
\hline 394.05 & 0 & 0 \\
\hline 395.05 & 0 & 0 \\
\hline 396.05 & 0 & 0 \\
\hline 397.05 & 0 & 0 \\
\hline 398.05 & 0 & 0 \\
\hline 399.05 & 1 & 0 \\
\hline 400.05 & 0 & 0 \\
\hline DTALI & 157 & 270 \\
\hline
\end{tabular}

NUMBER of CLASTS PER LITOLOGY

\begin{tabular}{|c|c|c|c|c|c|c|}
\hline \multicolumn{3}{|c|}{ DOL ts+Beacon) (INTRACL) } & VOLC & POM & METAM & tot \\
\hline 0 & 2 & 0 & 68 & 0 & 5 & 83 \\
\hline 0 & 4 & 0 & 0 & 0 & 3 & 11 \\
\hline 0 & 1 & 0 & 105 & 0 & 8 & 128 \\
\hline 0 & 2 & 0 & 123 & 0 & 5 & 136 \\
\hline 0 & 7 & 0 & 114 & 0 & 17 & 148 \\
\hline 0 & 5 & 0 & 78 & 0 & 4 & 97 \\
\hline 0 & 4 & 0 & 78 & 0 & 0 & 84 \\
\hline 0 & 4 & 0 & 57 & 0 & 6 & 74 \\
\hline 0 & 0 & 0 & 76 & 0 & 19 & 101 \\
\hline 0 & 4 & 0 & 36 & 0 & 0 & 41 \\
\hline 0 & 2 & 0 & 46 & 0 & 3 & 51 \\
\hline 0 & 0 & 0 & 17 & 0 & 2 & 19 \\
\hline 0 & 0 & 0 & 40 & 0 & 8 & 50 \\
\hline 0 & 5 & 0 & 40 & 0 & 15 & 63 \\
\hline 0 & 1 & 0 & 35 & 0 & 13 & 59 \\
\hline 0 & 0 & 0 & 0 & 0 & 0 & 0 \\
\hline 0 & 0 & 0 & 0 & 0 & 0 & 0 \\
\hline 0 & 0 & 0 & 0 & 0 & 0 & 0 \\
\hline 0 & 1 & 2 & 4 & 0 & 6 & 15 \\
\hline 0 & 0 & 0 & 1 & 0 & 5 & 7 \\
\hline 0 & 0 & 0 & 0 & 0 & 0 & 0 \\
\hline 0 & 0 & 1 & 0 & 0 & 0 & 1 \\
\hline 0 & 2 & 5 & 7 & 0 & 0 & 14 \\
\hline 0 & 0 & 0 & 6 & 0 & 0 & 6 \\
\hline 0 & 0 & 0 & 10 & 0 & 0 & 10 \\
\hline 0 & 0 & 3 & 1 & 0 & 0 & 4 \\
\hline 0 & 0 & 1 & 2 & 0 & 0 & 3 \\
\hline 0 & 0 & 9 & 4 & 0 & 0 & 13 \\
\hline 0 & 1 & 4 & 2 & 0 & 0 & 7 \\
\hline 0 & 0 & 5 & 6 & 0 & 0 & 11 \\
\hline 0 & 0 & 11 & 29 & 0 & 0 & 40 \\
\hline 0 & 0 & 1 & 2 & 0 & 0 & 4 \\
\hline 0 & 2 & 1 & 10 & 0 & 0 & 13 \\
\hline 5 & 125 & 43 & 5782 & 0 & 339 & 6721 \\
\hline
\end{tabular}

